\title{
Dramın Boyutlarının Ölçümü: Terörizmin Sosyo-Ekonomik Belirleyicilerinin Coğrafi Ağırlıkı Regresyon Analizi
}

\author{
Merter AKINCI ${ }^{1}$, Gönül YÜCE AKINCI ${ }^{2}$, Ömer YILMAZ ${ }^{3}$
}

\section{Measuring the Extents of Drama: A Geographically Weighted Regression Analysis of}

\section{the Socio-Economic Determinants of Terrorism}

\begin{tabular}{l} 
ARTICLE INFO \\
\hline Article History: \\
Date Submitted: 15.08 .2017 \\
Date Accepted: 11.10 .2017 \\
\hline JEL Classification: \\
C31 \\
F51 \\
O50 \\
P16
\end{tabular}

Keywords:

Terrorism

Socio-economic

Determinants

Geographically Weighted

Regression

Turkish Economy

\begin{abstract}
In the study, the socio-economic determinants of terrorism are examined using Geographically Weighted Regression (GWR) analysis in the context of 81 provinces in Turkey. Firstly, on the purpose of investigating the validity of convergence process among the provinces and examining the effects of terrorism on the convergence process, the four regression models of convergence are used. The results of unconditional and conditional convergence analysis show that divergence process among the provinces is dominant and that terrorism accelerates divergence process. Secondly, the model estimation findings point out that the GWR model promotes the model fitting compared to global estimation coefficients. The outcomes of the analysis providing the non-linear relationship between the terrorism, income and democracy show that the roots of terrorism are stem from several factors in Turkey. In general, it is observed that the level of income, population, unemployment, foreign trade, inflation, poverty, inequality, crime rate, democracy, ethnic heterogeneity, residential instability and geographic location have a positive impact of terrorism while the level of education, consumption, hopefulness, happiness and military intervention have a negative effect on terrorist activity.
\end{abstract}

\footnotetext{
${ }^{1}$ Yrd. Doç. Dr., Ordu Üniversitesi, İktisadi ve İdari Bilimler Fakültesi, İktisat Bölümü Öğretim Üyesi, makinci86@gmail.com

${ }^{2}$ Yrd. Doç. Dr., Ordu Üniversitesi, Ünye İktisadi İdari Bilimler Fakültesi, İşletme Bölümü Öğretim Üyesi, gyuce81@gmail.com

${ }_{3}^{3}$ Prof. Dr., Atatürk Üniversitesi, İktisadi ve İdari Bilimler Fakültesi, Ekonometri Bölümü Öğretim Üyesi, omeryilmaz@atauni.edu.tr
} 


\section{Özet}

Bu çalışmada, Türkiye'de 81 il bazında terörizmin sosyo-ekonomik belirleyicileri Coğrafi Ağırlıklı Regresyon (GWR) analizi kullanılarak incelenmiştir. İlk olarak, iller arasında yakınsama sürecinin geçerliliğini ve terörizmin bu süreç üzerindeki etkisini araştırabilmek amacıyla dört yakınsama regresyonundan yararlanılmıştır. Koşulsuz ve koşullu yakınsama analiz sonuçları, iller arasında ıraksama sürecinin baskın olduğunu ve terörizmin ıraksama sürecini hızlandırdığını göstermiştir. İkinci olarak, model tahmin sonuçları, global tahmin katsayılarına kıyasla GWR analizinin modellerin uyum düzeyini artırdığını göstermiştir. Terörizm ile gelir ve demokrasi arasında lineer-olmayan ilişkilerin varlığını kanıtlayan analiz bulguları, Türkiye'de terörizmin temel sosyo-ekonomik kökenlerinin çeşitli etkenlerden kaynaklandığını göstermiştir. Genel olarak; gelir, nüfus, işsizlik, ticaret, enflasyon, yoksulluk, eşitsizlik, suç oranı, demokrasi, etnik ayrımcılık, yerleşik istikrarsızlığı ve coğrafik faktörlerin terörizm üzerinde pozitif yönlü bir etkiye sahip olduğu gözlenmesine karşın; eğitim, tüketim, umut, mutluluk ve askeri müdahale düzeyinin ise negatif yönlü bir etkiye sahip olduğu ortaya konmuştur.

Anahtar Kelimeler: Terörizm, Sosyo-Ekonomik Belirleyiciler, Coğrafi Ağırlıklı Regresyon Analizi, Türkiye Ekonomisi

\section{Giriş}

1970’li yıllardan itibaren dünya gündemindeki yerini almış olsa da bünyesinde kavramsal problemleri barındıran terörizm olgusu, uluslararası düzeyde kabul edilen bir tanımlamaya henüz sahip değildir. Genel bir kanı olarak ifade edilen "birinin teröristi, diğerinin özgürlük savaşçısıdır" ş̧eklindeki terminoloji ${ }^{4}$, konunun hala muğlak tanımsal sorunları bünyesinde barındırdığını ortaya koymaktadır. Temel olarak terörizm; çeşitli alt grupların, kendi isteklerini kabul ettirebilmek amaciyla toplumdaki sivil kesimler ile silahlı ve silahsız askeri birimlere karşı gerçekleştirdikleri planlı ve siyasi olarak desteklenmiş şiddet bazlı faaliyetler olarak tanımlanmaktadır (Sönmez ve Graefe, 1998, s. 117; Akıncı ve Yılmaz, 2015, s. 52). Bir diğer ifadeyle terörizm; kişisel, sosyal, ekonomik ve politik kazançlar elde edebilmek

\footnotetext{
${ }^{4}$ Orijinali, "One man's terrorist is another man's freedom fighter" olan bu ifade ilk kez Amerikan basssavcısı W. Ramsey Clark tarafindan kullanılmıştır.
} 
amacıyla toplum için önem arz eden gruplara bir baskı uygulayarak kasıtlı şiddet içeren eylemlerin yapılması ve dolayısıyla hedef kitlenin doğrudan eylem bazlı uyarılmasıdır. Bu ifade çerçevesinde ekonomi biliminde geçerli olan çok sayıda terörizm tanımı yapılabilmekte, ancak terörist faaliyetler için sıklıkla kullanılan ve üç faktörden oluşan bir kombinasyon daha çok tercih edilmektedir. Bunlar; (a) aşırı şiddet içerikli eylemlerin gerçekleştirilmesi, (b) bireyler ve organizasyonlar tarafından terörist grupların oluşturularak faaliyete geçirilmesi ve (c) bu grupların amaçlarını anlatan propagandaların yaygınlaştırılmasıdır (Shahbaz ve Shabbir, 2011, s. 2; Akınc1, Yüce-Akınc1 ve Yılmaz, 2015, s. 2). Bununla birlikte, söz konusu bu faaliyetlerin ${ }^{5}$ birden fazla ülkenin topraklarını ve vatandaşlarını hedef alması durumunda uluslararası terörizm olgusundan bahsedilmektedir. Anlaşılacağ1 üzere, temel bir grubu hedef almak kaydıyla toplumun geniş kesimlerinde şiddet eylemleri ile birlikte tansiyonu yükseltmeyi ve korku üzerine kurulu bir yapılanmayı amaçlayan terörist faaliyetler, kamusal otorite zafiyetinden beslenerek çoğunlukla arzulanan hedefi gerçekleştirmekte (Yıldırım, Öcal ve Korucu, 2007, s. 6; Akınc1, Yüce-Akınc1 ve Y1lmaz, 2015, s. 2) ve uzun dönemde ise gücün, etki potansiyelinin ve refahın yeniden dağılımını hedeflemektedir. Söz konusu bu etkilerinden dolayı terörizmin özellikle savunma ekonomisi üzerinde çeşitli kanallar vasıtasıyla büyük tahribatlar yarattığı, ancak temel yıkıcı unsurun ise ekonomik büyüme sürecini doğrudan etkileyen çeşitli mekanizmalardan kaynaklandığı söylenebilir.

Ekonomi üzerinde yarattığı tahribatın etkilerini anlayabilmek amacıyla bu çalışmanın amac1, terörizmin sosyal ve ekonomik belirleyicilerini Türkiye ekonomisinde iller bazında Coğrafi Ağırlıklı Regresyon Analizi kullanarak araştırmaktır. Söz konusu bu çalışmayı literatürde yer alan ve Türkiye ekonomisi için yapılan diğer çalışmalardan üstün kılan temel özellik ise, terörizmin sosyal ve ekonomik determinantlarının iller bazında saptanması ve her bir ilin terörizm kaynaklı ekonomik yoksunluk şiddetinin modelleme sürecine dâhil edilmesidir. Söz konusu bu sürecin, geniş bir veri seti yardımıyla ve ekonometrik metodolojide yeni sayılan Coğrafi Ağırlıklı Regresyon Analizi ile işletilmesi de çalışmanın güncelliğine ilave bir katkı sağlamaktadır. Terörizmin belirleyicilerinin saptanmasının yanı sıra, iller arasındaki yakınsama sürecinin incelendiği ve terörizmin bu süreç üzerindeki etkisinin ne olduğu sorusunun cevabının da arandığı çalışmada, terörizm ile gelir düzeyi arasında kuadratik (lineer olmayan) bir ilişkinin

\footnotetext{
51972 yılında gerçekleştirilen Münih Olimpiyat Oyunları'nda İsrail atletlerine yönelik terör saldırılarında 11 kişi hayatını kaybetmiş ve dünya genelindeki 800 milyon kişi bugünkü anlamda terörizm olgusu ile karşılaşmıştır.
} 
olup olmadığı da tartışılmaktadır. İfade edilen analizler, çalışmanın geniş bir ilgi alanını bünyesinde barındırmasından dolayı literatüre doğrudan bir katkı sağlamayı hedeflemektedir. Bu kapsam dâhilinde çalışma yedi bölümden oluşmaktadır. Konunun teorik temellerinin ortaya konduğu ikinci bölümü takiben, terörizmin belirleyicileri kapsamında literatürde yapılan çalışmalar üçüncü bölümde yer alacaktır. Çalışmanın dördüncü bölümünde analizlere ilişkin veri seti ve model tanıtılacak, uygulama bulguları ise beşinci bölümde okuyucuya aktarılacaktır. Çalışma, genel bir değerlendirmenin yapıldığı sonuç bölümüyle sona erdirilecektir.

\section{Terörizmi Sosyo-Ekonomik Tabanda Açıklayan Teoriler}

Ekonomi literatürü itibariyle terörizm olgusu, yoğun bilgi birikimine ihtiyaç duyulan karmaşık ve ilgi çekici bir konudur. Bu özelliği dolayısıyla, terörizmi anlayabilme ve mahiyeti ile içeriğini kontrol altına alabilme umudu hükümetlerin ve akademik kesimin konuya odaklanma düzeyini önemli bir biçimde artırmaktadır. Söz konusu bu ilgi dolayısıyla ekonomi yazınında terörizmin temelini ortaya koyabilmek için çeşitli teoriler ön plana çıkarılmıştır. Krueger ve Maleckova (2004) tarafından vurgulandığı üzere, sosyo-ekonomik taban ekseninde terörist faaliyetler arz ve talep cephesinden kaynaklanan etkiler dolayısıyla kendini gösterebilmektedir. Arz yönlü etkiler, imtiyaz gücüne sahip eğitimli bireylerin siyasette daha fazla aktif rol alabilme olasılıklarından dolayı terör eylemlerini destekleme eğilimi içerisinde olabileceklerini ifade etmektedir. Talep yönlü etkiler ise, terör örgütlerinin, eylemlerini kolaylıkla başarıya ulaştırabilmeleri için daha üstün yetenekleri dolayısıyla iyi eğitimli bireyleri tercih edecekleri anlayışı üzerine kuruludur. Arz ve talep cephesi bağlamında terör eylemlerinin sosyo-ekonomik kökenleri iki ana görüş ekseninde açıklanabilmektedir. Bunlardan ilki olan ve Gurr (1968) tarafından ortaya atılan ekonomik yoksunluk argümanı, kötü ekonomik koşullar ile ekonomik firsat eşitliğindeki yetersizliklerin terörizmi beslediğini ve siyasi kanadın da bu sürece dâhil olduğunu yansitmaktadır. Olson (1963) tarafindan öne sürülen ve yoksullaştıran modernizasyon teoremi olarak adlandırılan ikinci görüş ise, ekonomik büyüme sürecine bağlı olarak gelir dağılımının mutlaka bir sosyal sınıf lehine bozulacağını ve diğer sosyal sınıfın elinde nefret duygularından başka hiçbir şeyin kalmayacağını ifade etmektedir. Terörizmin kökenlerini eşitsiz toplumsal yapıya bağlayan bu görüş, uzun dönemde sosyo-ekonomik değişimlerin sosyo-ekonomik koşulları değiştireceği öğretisi üzerine kurulmaktadır. 
Ekonomik yoksunluk ve yoksullaştıran modernizasyon teoremlerinden ayrı olarak terörizmi yaratan bir diğer faktör ise Huntington (1996) tarafından ifade edilen medeniyet çarpışması argümanıdır. Toplumsal gelişme sürecine bağlı olarak farklı kimlik yapılarına sahip grupların gerek aynı ülke içindeki farklı gruplarla ve gerekse de farklı ülkelerdeki gruplarla olan çıkar çatışmalarının şiddeti körüklediğini öne süren medeniyet çarpışması, terörizmin beslendiği bir kaynak olarak kendini göstermektedir. Terörist organizasyonlar için taraftar bulunmasını kolaylaştıran muhalif kimlik grupları, kimlik-odaklı ideolojilerin şiddet içerikli eylemlere dönüşmesine zemin hazırlamaktadır. Farklı alt-gruplar arasındaki sosyo-ekonomik ve politik ilişki formları genellikle rant peşinde koşma kaygılarını beslemekte ve Daniel, Arce ve Sandler (2003) tarafından da vurgulandığı üzere çıkar çatışmalarının nefret boyutu kazanması ile sonuçlanmaktadır.

Küresel politik ve ekonomik düzen ya da alış1lagelen ifade ile küreselleşme olgusu da uluslararası ölçek bağlamında terörizmi besleyen unsurlardan biri olarak değerlendirilmektedir. Ekonomik entegrasyon (ticari açıklık derecesi şeklinde ölçülmekte), dış politika (batılı ülkeler ile olan politik ilişkiler bazında ölçülmekte) ve müttefik yapısı (belirli bir organizasyona üyelik bağlamında ölçülmekte) gibi faktörler, ekonomik çıkarlarını zedelediği ve güven duygularını bertaraf ettiğinden dolayı küreselleşme sürecine karşı direnç gösteren gelişmekte olan ülkelerin nefret beslediği belirleyiciler olarak göze çarpmaktadır (Krieger ve Meierrieks, 2011, s. 8). Bergesen ve Lizardo (2004) tarafından belirtildiği üzere, toplumun gelenekçi duyguları daha ağır basan kesimi, dış ülke egemenliğine ve küresel modernizasyona karşı çıkabilmek amacıyla şiddet eğilimi içerisine girebilmekte ve bu kesim, adalet duygusundan mahrum olan küresel düzenin haksız uygulamalarına karşı girişilecek olan faaliyetler için kolaylıkla destek bulabilmektedir.

Bulaşma etkisi, terörizmin nedenlerini açıklayan bir diğer faktör olarak ele alınabilir. Midlarsky, Crenshaw ve Yoshida (1980) tarafından ortaya atılan bu görüşün arkasındaki ana fikir, zaman ve mekân boyutları itibariyle terörizmin, kendi kendine enerji veren güçlü bir doğal yapılanma olduğudur. Terörizmin ilk olarak geçici bulaşma etkisi ile kendini göstereceğini vurgulayan yazarlar, bir ülkede geçmiş dönemdeki terör faaliyetlerinin ${ }^{6}$ cari dönemde yeni terör

\footnotetext{
${ }^{6}$ Uygulamalı çalışmalarda geçmiş dönemde yaşanan terör eylemleri, terörizmi niceliksel olarak ölçen değişkenlerin gecikmeli değerlerinden yararlanılarak hesaplanmaktadır.
} 
eylemlerine yol açma olasılığı üzerinde durmaktadırlar. Terör faaliyetlerinden elde edilebilecek olan yüksek kazançlardan dolayı, bir terörist grubu için terör örgütünün kurulması bir üst fayda düzeyine geçilmesi olarak değerlendirilebilmektedir. İkinci aşamada terörizm, mekânsal bulaşma etkisi ile ortaya çıkabilmektedir. Bu etki, bir ülkede ortaya çıkan terör faaliyetlerinin ilgili ülkenin sınır komşularına yayılmasını ifade etmekte ve terör eylemlerinin komşu ülkelerde taklitsel bir süreçle başladığını vurgulamaktadır.

\section{Terörizmin Sosyo-Ekonomik Belirleyicilerine İlişkin Stilize Olgular}

Ekonomi literatürü itibariyle nispeten yeni bir çalışma sahası olduğu söylenebilen terörizm olgusu, akademisyenlerin ve politika yapıcılarının ilgisini çeken temel konulardan biri haline gelmiştir. Hamilton ve Hamilton (1983) tarafından yapılan öncü çalışmanın ardından büyük bir popülarite kazanan konu, pek çok yazar tarafından terörizm olgusunun farklı ülke ve metodoloji bazında incelendiği bir alan olmuştur. Uygulamalı analizler; terörizm ile gelir düzeyi, ekonomik büyüme, gelir dağılımı adaleti, yatırım düzeyi, istihdam, tüketim hacmi, sosyal harcama seviyesi, demokrasi, siyasi istikrar ve haklar, insani kalkınma düzeyi, gelişen insan hakları, ahlaki değer yargıları, kıyı kesimlerine yakınlık ve özgürlük düzeyi arasında genellikle negatif yönlü ilişkilerin varlığını göstermiştir. Buna karşın uygulamalı analizlerde; terörizm ile yoksulluk, enflasyon, ticari açıklık, nüfus, işsizlik, eğitim düzeyi, kamu kesimi büyüklüğü, askeri harcama düzeyi, finansal ve ekonomik krizler, sivil savaş, etkin grup varlığı, askeri müdahale, dil-din farklılığı ve kentleşme düzeyi arasında ise pozitif yönlü ilişkilerin geçerli olduğu saptanmıştır.

Gerek toplumsal yap1 ve gerekse sosyo-ekonomik gelişim düzeyi üzerinde ortaya çıkardığı tahribat gücü dolayısıyla terörizmin arkasındaki mantığı anlamaya çalışan uygulamalı analizlerin elde ettiği temel sonuçlar Tablo 1'de gösterilmiştir. 
FSECON AKINCI, M., AKINCI YÜCE, G., YILMAZ, Ö., (2017), "Dramın Boyutlarının Ölçümü: Terörizmin Sosyo-Ekonomik

Belirleyicilerinin Coğrafi Ağırlkkl Regresyon Analizi", Fiscaoeconomia, Vol.1(3), 68-107.

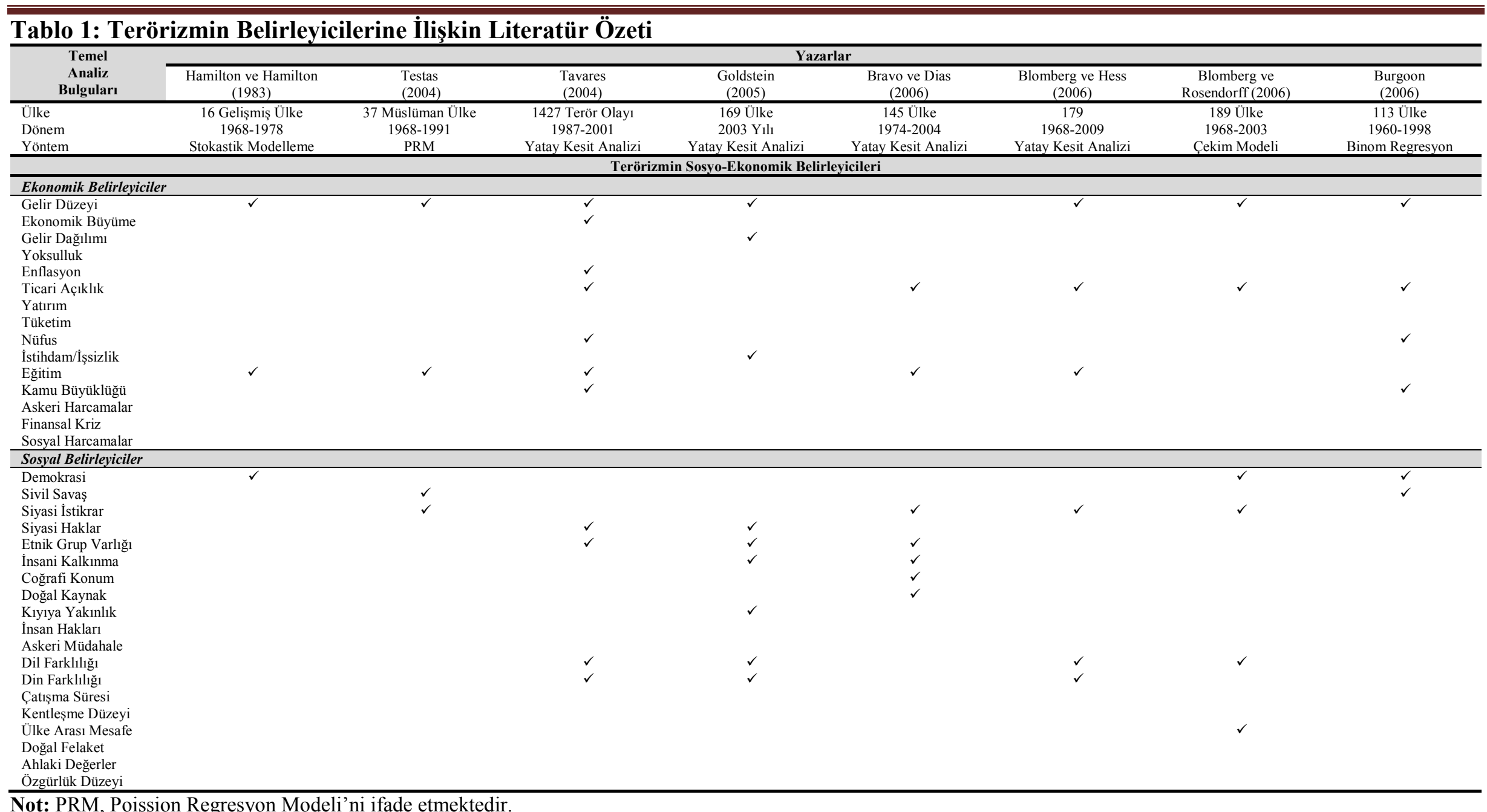


FSECON AKINCI, M., AKINCI YÜCE, G., YILMAZ, Ö., (2017), "Dramın Boyutlarının Ölçümü: Terörizmin Sosyo-Ekonomik

Belirleyicilerinin Coğrafi Ağırlkkl Regresyon Analizi", Fiscaoeconomia, Vol.1(3), 68-107.

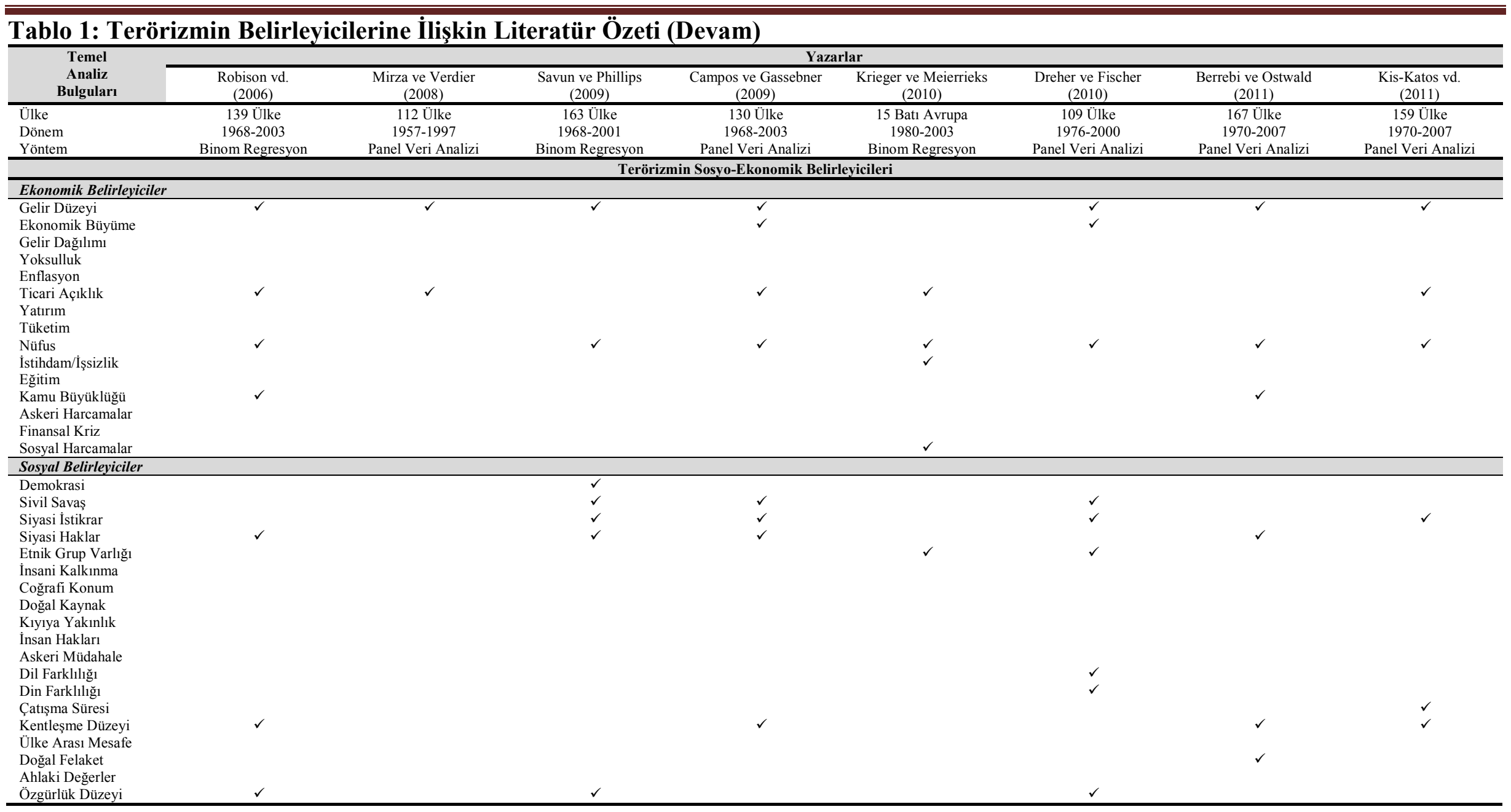


FSECON AKINCI, M., AKINCI YÜCE, G., YILMAZ, Ö., (2017), "Dramın Boyutlarının Ölçümü: Terörizmin Sosyo-Ekonomik

Belirleyicilerinin Coğrafi Ağırllkll Regresyon Analizi”, Fiscaoeconomia, Vol.1(3), 68-107

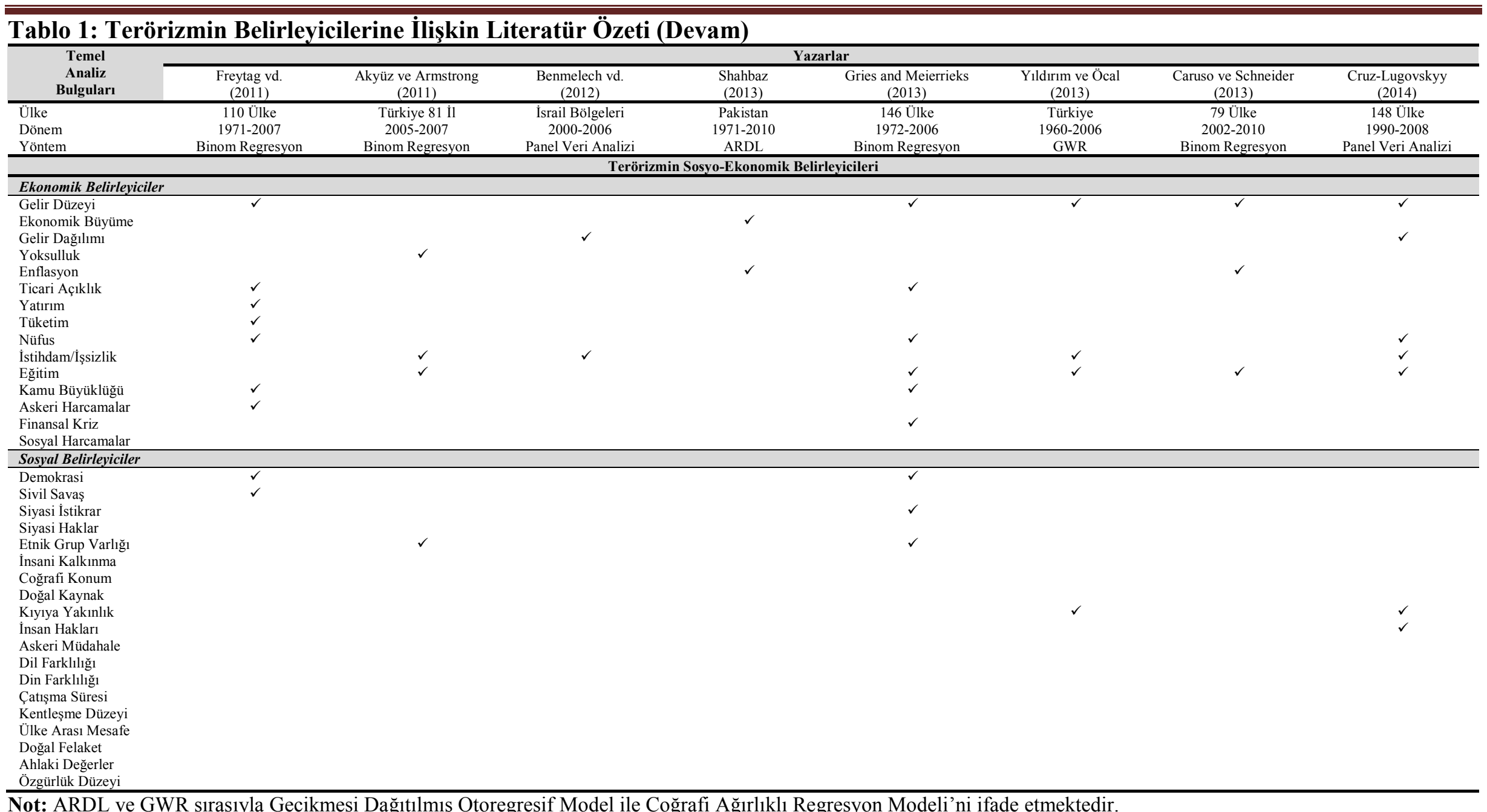


FSECON AKINCI, M., AKINCI YÜCE, G., YILMAZ, Ö., (2017), "Dramın Boyutlarının Ölçümü: Terörizmin Sosyo-Ekonomik

Belirleyicilerinin Coğrafi Ağırlıkl Regresyon Analizi”, Fiscaoeconomia, Vol.1(3), 68-107.

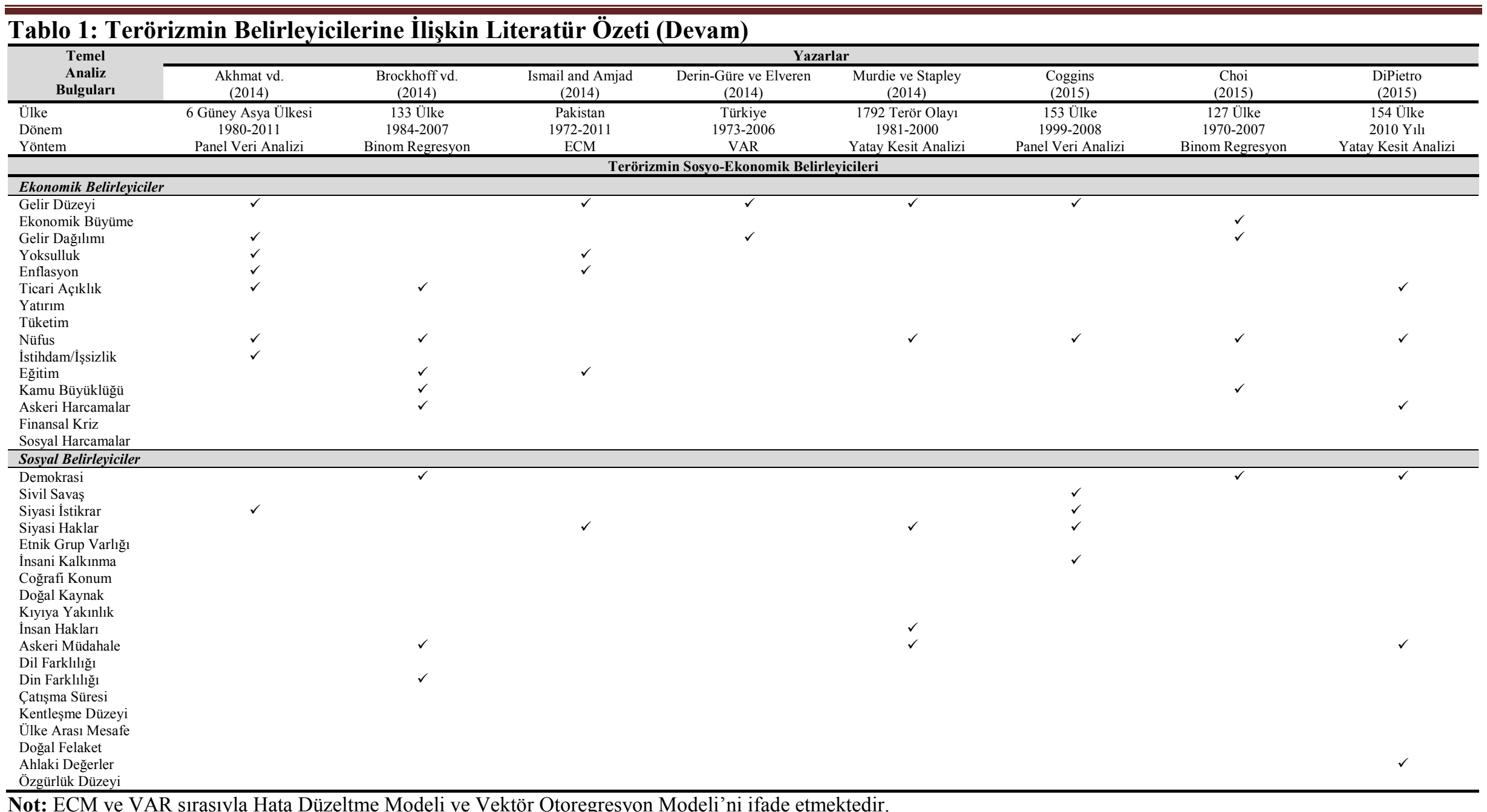




\section{Veri Seti ve Ekonometrik Metodoloji}

Bu kısımda ilk olarak çalışmaya ilişskin veri seti sunulacak ve değişkenlere ait bazı temel bilgiler aktarılacaktır. İkinci kısımda ise çalışmanın ekonometrik altyapısını oluşturacak metodolojik bilgiler ile regresyon modeli tanıtılacaktır. Metodoloji ekseninde yakınsama sürecine ilişkin temel bilgiler aktarıldıktan sonra GWR analizi detaylı olarak tartışılacaktır.

\subsection{Veri Seti}

$\mathrm{Bu}$ çalışmada, terörizmin sosyal ve ekonomik belirleyicileri Türkiye ekonomisinde 81 il bazında Coğrafi Ağırlıklı Regresyon Modeli (GWR) ve yatay kesit analizleri yardımıyla incelenmiştir. İlgili dönemin dikkate alınmasının temel nedeni, verilere ulaşabilme imkânından kaynaklanmıştır. Yatay kesit sistemini oluşturan veriler Global Terrorism Database, Türkiye İstatistik Kurumu (TÜİK), Yüksek Seçim Kurulu (YSK), Yüksek Öğretim Kurumu (YÖK) ve Karayolları Genel Müdürlüğü (KGM) resmi internet sitelerinden elde edilmiştir.

Terörizmin belirleyicilerinin saptanmasının yanı sıra, iller arasındaki yakınsama sürecinin terörizme bağlı olarak gerçekleşip gerçekleşmediği sorusunun cevabının da arandığ bu çalışmada, terörizm ile gelir ve demokrasi düzeyi arasında kuadratik (lineer olmayan) bir ilişkinin olup olmadığı da tartışılmaktadır. İfade edilen analizler, çalışmanın geniş bir ilgi alanını bünyesinde barındırmasından dolayı literatüre doğrudan bir katkı sağlamayı hedeflemektedir. Bir bağımlı değişken ile 10'u ekonomik temelli ve 12'si ise sosyal temelli olmak üzere toplam 22 bağımsız değişkenden oluşacak analizler için hazırlanan Tablo 2, çalışmaya konu olan değişkenlere ilişkin temel bilgileri yansıtmaktadır. 


\begin{tabular}{|c|c|c|c|c|c|}
\hline Veri Tanımı & Kisaltma & Veri Kapsamı & Birim & YII & Kaynak \\
\hline \multicolumn{6}{|c|}{ Bağımlı Değişken } \\
\hline $\begin{array}{c}\text { Terörizm } \\
\text { Düzeyi }\end{array}$ & Terör & $\begin{array}{l}\text { Terör Eylemleri Dolayısıyla Hayatını } \\
\text { Kaybedenler ve Yaralananlar }\end{array}$ & $\begin{array}{l}\text { Ölü ve Yaralı Toplam } \\
\text { Kiși Sayısı }\end{array}$ & $\begin{array}{c}2014 \\
\text { Yll1 } \\
\end{array}$ & $\begin{array}{l}\text { Global Terrorism } \\
\text { Database }\end{array}$ \\
\hline \multicolumn{6}{|c|}{ Bağımsız Değiskenler: Makroekonomik Belirleyiciler } \\
\hline Gelir Düzeyi & Gelir (+/-) & Kişi Başına Düşen Gayrisafi Katma Değer & ABD Doları & $2014 \mathrm{Y}_{11}$ & TÜiK \\
\hline $\begin{array}{c}\text { Gelir } \\
\text { Düzeyi }\end{array}$ & $\begin{array}{c}\text { Gelir }^{2} \\
(-)\end{array}$ & $\begin{array}{l}\text { Kişi Başına Düssen Gayrisafi } \\
\text { Katma Değerin Karesi }\end{array}$ & ABD Doları & $2014 \mathrm{Y}_{11}$ & $\begin{array}{l}\text { TÜIK Verilerinden Hareketle Kendi } \\
\text { Hesaplamalarımız }\end{array}$ \\
\hline Nüfus Düzeyi & Nüfus $(+)$ & Il'de Yaşayan Toplam Kişi Sayısı & İl Toplam Nüfusu & $2014 \mathrm{Y}_{11}$ & TÜiK \\
\hline Eğitim Düzeyi & Eğitim $(+/-)$ & İlköğretim, Ortaokul, Lise ve Yükseköğretimde Net Okullaşma Oranı & $\%$ & 2013 Y1l1 & YÖK, TÜIK \\
\hline İşsizlik Oranı & İşsizlik (+) & Çallşsmayan Kişi Sayısının Kurumsal Olmayan Nüfus İçindeki Oranı & $\%$ & 2013 Y1li & TÜIK \\
\hline $\begin{array}{c}\text { Ticari } \\
\text { Açılkk }\end{array}$ & $\begin{array}{c}\text { Ticaret } \\
(+/-)\end{array}$ & $\begin{array}{c}\text { Kişi Başına Dişa Açıllık Oranı } \\
\text { (Kişi Başına İhracat + Kişi Başına Itthalat)/Kişi Başına Gelir }\end{array}$ & $\%$ & 2014 Y1li & TÜiK \\
\hline Enflasyon Oranı & Enflasyon $(+)$ & Tüketim Harcamalarına İlisiskin Fiyat Düzeyi Endeksi & Endeks & 2014 Y1li & TÜIK \\
\hline Yoksulluk Düzeyi & Yoksulluk (+) & Medyan Gelirin \%50'sine Göre Yoksulluk Oranı & $\%$ & $2014 Y_{11}$ & TÜIKIK \\
\hline Gelir Dağıılımı & Eşitsizlik (+) & Gini Katsayı1s1 & Değer & 2014 Y1li & TÜİK \\
\hline $\begin{array}{c}\text { Tüketim } \\
\text { Düzeyi }\end{array}$ & $\begin{array}{c}\text { Tüketim } \\
(-)\end{array}$ & $\begin{array}{l}\text { Gıda, Giyim, Sağlık, Haberleşme ve Eğitim Alanlarına Yapılan Harcamaların Toplam } \\
\text { Harcama Düzeyi İçindeki Oranı }\end{array}$ & $\%$ & 2014 Yill & TÜiK \\
\hline \multicolumn{6}{|c|}{ Bağımsız Değişkenler: Sosyal Belirleyiciler } \\
\hline Umut Düzeyi & Umut (-) & Gelecek İle İlgili Beklenen Umut Algısı & $\%$ & 2013 Y1li & TÜIK \\
\hline Mutluluk Düzeyi & Mutluluk (-) & Yaşam Düzeyine Olan Memnuniyet & $\%$ & 2013 Y1li & TÜİK \\
\hline Suç Seviyesi & Suç $(+)$ & Il'de Suç İşleyen Toplam Kişi Sayısı & Toplam Kişi Sayısı & 2014 Y1li & TÜİK \\
\hline Demokrasi Seviyesi & Demokrasi $(+/-)$ & 1 Kasım 2015 Genel Seçimlerine Katıllım Oranı & $\%$ & 2015 Y1li & TÜiK \\
\hline $\begin{array}{c}\text { Demokrasi } \\
\text { Seviyesi }\end{array}$ & $\begin{array}{c}\text { Demokrasi }{ }^{2} \\
(-)\end{array}$ & $\begin{array}{c}1 \text { Kasım } 2015 \text { Genel Seçimlerine } \\
\text { Katılım Oranı } \\
\end{array}$ & $\%$ & 2015 Ylli & $\begin{array}{l}\text { TÜIK Verilerinden Hareketle Kendi } \\
\text { Hesaplamalarımız }\end{array}$ \\
\hline $\begin{array}{c}\text { Etnik } \\
\text { Ayrişma }\end{array}$ & $\begin{array}{c}\text { Etnik } \\
(-)\end{array}$ & $\begin{array}{l}\text { İl İçerisindeki Etnik } \\
\text { Ayrışma Düzeyi }\end{array}$ & Değer & 2015 Yill & $\begin{array}{l}\text { YSK Verilerinden Hareketle Kendi } \\
\text { Hesaplamalarımız }\end{array}$ \\
\hline $\begin{array}{c}\text { Kiy1 } \\
\text { Kesimi }\end{array}$ & $\begin{array}{c}\text { Kiy1 } \\
(+)\end{array}$ & $\begin{array}{c}\text { İlin Kıy1 Kesimlerine Olan } \\
\text { Uzaklık Durumu (Kıyı=0, Diğer=1) }\end{array}$ & Kukla Değişken & - & - \\
\hline $\begin{array}{c}\text { Yerleşik } \\
\text { İstikrarszly̆ğı } \\
\end{array}$ & $\begin{array}{c}\text { Yerleşik } \\
(+)\end{array}$ & $\begin{array}{c}\text { Yerleşiklerin } \\
\text { Göç Hareketleri } \\
\end{array}$ & $\%$ & 2014 Yill & $\begin{array}{c}\text { TÜIK Verilerinden Hareketle Kendi } \\
\text { Hesaplamalarımız } \\
\end{array}$ \\
\hline Çatış̧ma Düzeyi & Çatışma (+/-) & $\begin{array}{c}\text { Askeri Kuvvetler ile Terör Örgütleri Arasındaki Çatı̧̧̧ Durumu (Askeri Müdahale=1, } \\
\text { Diğer }=0 \text { ) }\end{array}$ & Kukla Değişken & - & - \\
\hline Coğrafi Konum & Coğrafya (+) & $\begin{array}{c}\text { Terör Eylemlerinin Yoğun Olarak Gerçekleştiği İllere Yakınlık } \\
\text { (İlgili Ile Komşu Olma Durumu=1, Diğer=0) }\end{array}$ & Kukla Değişken & - & - \\
\hline İller Arası Mesafe & Uzaklık (-) & $\begin{array}{c}\text { Terör Eylemlerinin En Yoğun Olarak Gerçekleştiği İle (Hakkâri) } \\
\text { Olan Uzaklık }\end{array}$ & $\mathrm{Km}$ & - & KGM \\
\hline Kentleşme Düzeyi & Kent $(+/-)$ & İl ve İlçe Merkezleri Nüfusunun Toplam Nüfus İçindeki Oranı & $\%$ & $2014 \mathrm{Y}_{11}$ & TÜİK \\
\hline
\end{tabular}

Not: Değişkenlere ait kısaltmaların yanında bulunan parantez içindeki işaretler, ekonometrik analizler için beklenen katsayı işaretlerini yansıtmaktadır. 
Analizler için geçerli olan ekonometrik metodolojinin tanıtılmasından önce bazı değişkenler ile ilgili olarak gerekli olan açıklamaların yapılması büyük bir önem arz etmektedir. İlerleyen eğitim sürecinin terörizm üzerindeki etkilerini irdeleyebilmek adına analizlerde kullanılan bir diğer değişken yükseköğretimde net okullaşma oranıdır. TÜİK veri tabanında bulunmayan bu değişkenin değerinin hesaplanabilmesi için,

Yüksek Öğretimde Net Okullaşma Oranı $=\frac{\text { Teorik Yaş Grubundaki Toplam Öğrenci Sayısı }}{\text { Teorik Yaş Grubundaki Toplam Nüfus }}$

formülünden yararlanılmıştır. Yükseköğretim kurumlarında okuyan öğrenciler için teorik yaş grubu olarak 20-24 yaş aralığı dikkate alınmıştır.

Toplumda etnik ayrışmanın boyutlarını anlayabilmek ve bu değişkenin terörizme neden olup olmadığını sınayabilmek için Blau (1977) ve Blau, Blum ve Schwartz (1982) tarafından geliştirilen nüfus farklılaşma metodolojisinden yararlanılmış ve (2) numaralı eşitlik yardımıyla hesaplanmıştır:

$H=1-\sum p^{2}$

(2) numaralı eşitlikte yer alan $H$, nüfus farklılaşma düzeyini ve $p$ ise belirli bir grup itibariyle nüfustaki kırılma potansiyelini yansıtmaktadır. Etnik ayrışma düzeyini saptayabilmek için 1 Kasım 2015 seçimlerinde etnik bakımdan Türkiye'deki en ayrılıkçı partinin aldığı oyların geçerli toplam oy sayısı içindeki oranından hareket edilmiştir. Bu değişken itibariyle dikkate alınması gereken temel nokta, $H$ değeri düştükçe etnik ayrışma seviyesinin artma eğilimi içinde olduğudur. Dolayısıyla, etnik ayrışma değişkeni bakımından ekonometrik analizlerde elde edilebilecek olan negatif işaretli bir katsayı, etnik ayrışa seviyesinin terörist faaliyetleri tetiklediği şeklinde yorumlanmalıdır.

Yerleşik istikrarsızlığının, bir diğer deyişle ülke içerisindeki sürekli göç dalgasının terör eylemlerine yol açıp açmadığını saptayabilmek adına Akyüz ve Armstrong (2011) tarafından geliştirilen ölçüm tekniğinden yararlanılmış ve (3) numaralı eşitlik kullanılarak il bazında yerleşik istikrarsızlı̆̆ı hesaplanmıştır: 
İllerin gelir düzeylerinin belirlenmesinde TÜİK'den elde edilen ve ABD doları bazında ifade edilen kişi başına düşen gayrisafi katma değer rakamları kullanılmıştır. İl bazındaki bu veri seti yalnızca 2004-2011 dönemi için mevcuttur. 2014 y1lı değerlerinin saptanabilmesi amaciyla,

$$
Y_{t+n}=(1+g)^{n} Y_{t}
$$

olarak ifade edilen öngörü formülünden yararlanılmıştır. (4) numaralı eşitlikte yer alan $Y_{t+n}$, tahmin edilecek olan dönemdeki kişi başına düşen gayrisafi katma değeri; $Y_{t}$, cari dönem kişi başına düşen gayrisafi katma değeri; $g$, kişi başına düşen gayrisafi katma değerin büyüme oranını; $n$, dönem sayısını ve $t$ ise zaman dilimini ifade etmektedir. $g$ değerini hesaplayabilmek için,

$g=\left(\frac{\text { Dönem Sonu Kişi Başına Düşen Reel GSYİH }}{\text { Dönem Başı Kişi Başına Düşen Reel GSYİH }}\right)^{1 / n}-1$

olarak gösterilen uzun dönemli büyüme oranı formülünden yararlanılmıştır. (4) ve (5) numaralı eşitliklerin eşanlı olarak kullanılması neticesinde her il için 2014 yılı kişi başına düşen gayrisafi katma değer rakamları elde edilmiştir.

\subsection{Ekonometrik Metodoloji ve Model}

Neoklasik ekol ile birlikte gündeme gelen yakınsama kavramı Solow (1956) öncülüğünde geliştirilmiş ve yakınsama süreci, azgelişmiş ya da gelişmekte olan ülke ve bölgelerin gelişmiş ülke ya da bölgelere kıyasla daha hızlı büyüyecekleri ve zamanla iki grup arasındaki kişi başına düşen gelir düzeyi farklarının kapanacağı biçiminde tanımlamıştır. Yakınsama hipotezinin temeli, kişi başına düşen gelirin dönem başı değeri ile bu gelirdeki büyüme hızı arasında negatif yönlü bir ilişkinin bulunmasına dayanmaktadır. Solow (1956) tarafından gerçekleştirilen öncü çalışmayı takiben içsel büyüme modellerinin kurucusu olarak nitelendirilen Romer (1986) ve Barro ve Sala-i-Martin (1991) tarafından yapılan çalışmalar, 
yakınsama olgusuna olan ilginin artmasına zemin hazırlamıştır. Yatay kesit verilerini kullanarak ülkeler ya da bölgeler arasındaki yakınsama sürecinin saptanmasında genellikle (6) numaralı regresyon denkleminden yararlanılmakta ve bu süreç beta yakınsaması olarak ifade edilmektedir:

$\log \left(\frac{y_{i t}}{y_{i, t-1}}\right)=a+\beta \log \left(y_{i, t-1}\right)+u_{i t}$

(6) numaralı eşitlikte yer alan $y_{i t}, t$ döneminde kişi başına düşen gelir düzeyini; $y_{i, t-1}$, belirli bir başlangıç dönemini yansıtan $t$ - 1 periyodunda kişi başına düşen gelir düzeyini; $a$, sabit terimi ve $u_{i t}$ ise beyaz gürültü hata terimini göstermektedir. (6) numaralı regresyon denkleminde $\beta$ katsayısının negatif değer alması durumunda yakınsama, aksi halde ise ıraksama sürecinden bahsedilmektedir. Türkiye ekonomisi dikkate alındığında, kişi başına düşen gayrisafi katma değerin en fazla olduğu ilin İstanbul (2014 yılı öngörü değeri itibariyle kişi başına gayrisafi katma değer 18318 ABD doları) olduğu görülmektedir. Bu bağlamda, yapılacak analizlerde üzerinde durulacak olan temel husus, diğer illerin İstanbul'a olan yakınsama sürecinin incelenmesi ve terörizmin bu süreç üzerindeki etkisi olacaktır. Dolayısıyla (6) numaralı beta yakınsama regresyon eşitliği, diğer illerin İstanbul'a olan yakınsama süreci ve terörizmin etkileri bağlamında yeniden yazıldığında,

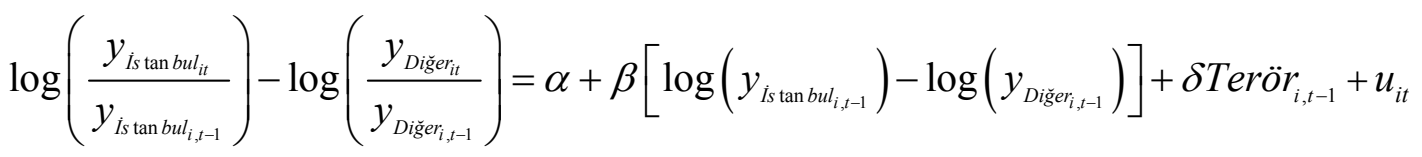

olarak ifade edilebilmektedir. (7) numaralı regresyon denkleminde yer alan $\delta$ katsayısı, terör eylemlerinin yakınsama sürecine olan etkisini yansıtmaktadır. (7) numaralı denklem itibariyle gözden kaçırılmaması gereken temel nokta, bütün illerin aynı durağan durumda dengeye geldiğinin zımnen varsayılmasıdır. Bu varsayım her ne kadar katı bir unsur olarak değerlendirilebilse de, GWR analizi yardımıyla ilgili kısıt süreci ağırlık matrisleri kullanılarak aş1labilmektedir.

Türkiye'de terörist eylemler genellikle Güneydoğu bölgesinde ve bazı birkaç ilde kendini gösterdiğinden dolayı, terörizmin yoğunlaştığı illerin uğradığı ekonomik kayıplar daha 
büyük boyutlara ulaşmaktadır. $\mathrm{Bu}$ nedenle, terörizmin sosyo-ekonomik belirleyicileri araştırılırken Türkiye'deki bütün illerin benzer yapısal özelliklere sahip olacağı varsayımından hareket eden analizler nispeten yanıltıcı sonuçlara yol açabilmektedir. Dolayısıyla, farklı illerde farklı şekillerde yoğunlaşan terör eylemlerinin sosyo-ekonomik belirleyicilerinin yerel anlamda farklılaşan parametreler yardımıyla incelenmesi hususu büyük bir önem taşımaktadır. Yerel olarak farklılaşmış parametrelerin ekonometrik tahminine dayanan temel tekniklerden biri, GWR analizidir. Bu çalışmada, Türkiye'de terörizmin sosyo-ekonomik belirleyicilerinin saptanması sürecinde Öcal ve Yıldırım (2010) tarafından uygulanan metodolojiden yararlanılacaktır.

Parametrik olmayan bir mekânsal model işleyişini bünyesinde barındıran GWR analizi, alt-örneklem veri bilgilerini kullanarak uzaydaki her bir noktanın tahmin sürecini üretebilmek için yerel lineer regresyon sınamalarına dayanmaktadır. Bu yaklaşım, mesafe tabanlı ağırlıkları dikkate alarak her değişken ve her coğrafi alan için parametre tahminlerine olanak sağlamaktadır. Bu bağlamda GWR analizi, veri setindeki her il için yerel parametre değerlerinin elde edilmesine imkân tanımakta ve böylesi bir analiz ise iller arasında herhangi bir ayrım gözetmeksizin bütün veri setini olduğu gibi göz önünde bulunduran diğer yöntemlere k1yasla üstün bir metot olarak değerlendirilmektedir. GWR analizinde, her bir ilin bireysel regresyonu, mekânsal vekil düzeylerine göre ağırlıklandırılmaktadır. Böylece, parametrelerdeki mekânsal değişim mekânsal ağırlıklara göre düzleştirilerek, parametrelerdeki geniş kapsamlı bölgesel farklılıkların giderilmesi sağlanmış olmaktadır (Öcal ve Yıldırım, 2010, s. 483).

GWR analizi; En Küçük Kareler (OLS) yönteminin, bir bölge ile diğer bölgelerin katsayı tahminleri arasındaki uzaklığın bir fonksiyonu şeklindeki gözlem değerlerinin ağırlıklandırılmasıyla oluşan bir genişletilmiş modeldir. Dolayısıyla, parametre tahminleri Fotheringham, Charlton ve Brunsdon (1997) tarafından vurgulandığı üzere $i$ mekânı için spesifik bir konuma gelmektedir. GWR modeli genel olarak,

$Y_{i}=\alpha_{i 0}+\sum_{k=1}^{p} \alpha_{i k} X_{i k}+\varepsilon_{i}$

ifade edilmektedir. (8) numaralı regresyon denkleminde bağımlı değişken olarak yer alan $Y, k=1, \ldots, p$ 'ye kadar değer alan $X_{k}$ bağımsız değişkenlerinin kombinasyonundan 
oluşmaktadır. $\varepsilon_{i}$, sıfır ortalama ve sabit varyansa sahip normal dağılımlı "beyaz gürültü hata terimi” olarak denklemde yer almaktadır. $\alpha_{i k}$, her $i$ lokasyonu ve her $k$ değişkeni için regresyon katsayılarını vurgulamaktadır. $\alpha_{i 0}$ ise modelin sabit değişkenini yansıtmaktadır. (8) numaralı regresyon denklemi kullanılarak elde edilecek yerel tahminler, $i$ lokasyonunun diğer lokasyonlara mesafesinin bir fonksiyonu olan gözlemlerin ağırlıklandırılmasıyla oluşturulacak ağırlıklı regresyon model çözümü yardımıyla saptanmaktadır. $i$ lokasyonundaki parametre vektörleri ise,

$$
\hat{\alpha}_{i}=\left(X^{T} W_{i} X\right)^{-1} X^{T} W_{i} Y, \quad i=1, \ldots, n
$$

yardımıyla elde edilmektedir. (9) numaralı regresyon denkleminde yer alan $W_{i}$, her bir gözlem için yerel mekânsal ağırlık matrisini ifade etmektedir. GWR analizi parametre tahmin sürecindeki ana unsur, lokasyonlar arasındaki her bir gözlemin önemini temsil eden ağırlık matrisini oluşturmaktır. Mekânsal analizde; $i$ lokasyonunun, kendisine yakın olmayan bir alana kıyasla kendisine yakın olan bir alanı daha fazla etkileyeceği genel olarak kabul edilmektedir. Dolayısıyla, $i$ lokasyonundaki parametreler tahmin edilirken, $i$ lokasyonuna daha yakın alanlara daha fazla önemin verilmesi gerekmektedir. Bu bağlamda, ağırlık matrisini belirleyebilmenin doğal bir yolu, ters mesafe kriteri olarak adlandırılan $1 / d_{i j}$ sürecini işletmektir. Bu süreçte yer alan $d, i$ ve $j$ lokasyonları arasındaki ağırlığ 1 temsil etmektedir.

$i$ lokasyonundaki ağırlık matrisi, genellikle, spesifik bir mesafeye kıyasla daha uzak olan gözlemlerin dışlanması şeklinde oluşturulmaktadır. Bu durum, $i$ 'den $j$ 'ye olan uzaklığın, $d$ eşik değerli uzaklık parametresine kıyasla daha fazla olması durumunda $j$ gözlemine sıfır değerindeki ağırlığın verilmesi gerektiği şeklinde yorumlanmalıdır: (Öcal ve Yıldırım, 2010, s. 484)

Her $i, j=1, \ldots, n$ için $\left\{\begin{array}{lll}W_{i j}=1 & \text { eğer } & d_{i j} \leq d, \\ W_{i j}=0 & \text { eğer } & d_{i j}>d\end{array}\right.$ 
Ağırlık matrisinin elde edilmesini takiben GWR parametreleri, kalıntı kareleri toplamını minimum kılacak değerler tarafından seçilecek farklı $\alpha$ katsayıları kullanılarak tahmin edilebilmektedir:

$$
\sum_{i=1}^{n}\left[Y_{i}-Y_{i}^{*}(\alpha)\right]^{2}
$$

(10) numaralı denklemde yer alan $Y_{i}^{*}(\alpha), i$ lokasyonundaki $Y_{i}^{\prime}$ 'nin uyumlaştırılmış değerlerini yansıtmaktadır. $Y_{i}^{*}$ uyumlaştırılmış değerleri, $Y_{i}^{*}$ 'ın $X_{i}$ ve $\hat{\alpha}_{i k}$ parametrelerinin lineer kombinasyonları olmasından dolayı, her $\alpha_{i k}$ lokasyonunun tahminine dayanmaktadır (Öcal ve Yıldırım, 2010, s. 484).

Türkiye ekonomisinde terörizmin sosyo-ekonomik belirleyicilerinin saptanabilmesi amacıyla ekonomik ve sosyal belirleyiciler ayrı ayrı dikkate alınarak, ekonomik belirleyiciler için (11) ve sosyal belirleyiciler içinse (12) numaralı regresyon denklemlerinden yararlanılacaktır:

$$
\begin{aligned}
\text { Terör }_{i}= & \alpha_{0}+\alpha_{1} \text { Gelir }_{i} W_{i}+\alpha_{2} \text { Gelir }_{i}^{2} W_{i}+\alpha_{3} \text { Nüfus }_{i} W_{i}+\alpha_{4} \text { Ĕğitim }_{i} W_{i} \\
& +\alpha_{5} \dot{I}_{\text {Şsizlik }} W_{i}+\alpha_{6} \text { Ticaret }_{i} W_{i}+\alpha_{7} \text { Enflasyon }_{i} W_{i}+\alpha_{8} \text { Yoksulluk }_{i} W_{i} \\
& +\alpha_{9} \text { Eşitsizlik }_{i} W_{i}+\alpha_{10} \text { Tüketim }_{i} W_{i}+\varepsilon_{i}
\end{aligned}
$$

$$
\begin{aligned}
\text { Terör }_{i}= & \beta_{0}+\beta_{1} \text { Umut }_{i} W_{i}+\beta_{2} \text { Mutluluk }_{i} W_{i}+\beta_{3} \text { Suç }_{i} W_{i}+\beta_{4} \text { Demokrasi }_{i} W_{i} \\
& +\beta_{5} \text { Demokrasi }_{i}^{2} W_{i}+\beta_{6} \text { Etnik }_{i} W_{i}+\beta_{7} \text { Kıyl }_{i} W_{i}+\beta_{8} \text { Yerleşik }_{i} W_{i} \\
& +\beta_{9} \text { Çatışma }_{i} W_{i}+\beta_{10} \text { Coğrafya }_{i} W_{i}+\beta_{11} \text { Uzaklık }_{i}+\beta_{12} \text { Kent }_{i} W_{i}+\varepsilon_{i}
\end{aligned}
$$

(11) ve (12) numaral1 regresyon denklemlerinde yer alan $\alpha_{0}$ ve $\beta_{0}$, sabit terimi; $\alpha$ ve $\beta$; eğim parametrelerini; $W_{i}, i$ lokasyonuna ait coğrafi ağırlık değişkenini ve $\varepsilon_{i}$ ise beyaz gürültü hata terimini yansıtmaktadır. 


\section{Uygulama Bulguları}

Türkiye ekonomisi 81 il bazında terörizmin sosyal ve ekonomik belirleyicilerine ilişkin uygulama bulguları sunulmadan önce ilgili değişkenler arasındaki korelasyon ilișkileri ve bu ilişkilere ait anlamlılık durumları sınanmaya çalışılmıştır. Bu kapsam doğrultusunda hazırlanan Tablo 3, terörizm ile makroekonomik değişkenler ve Tablo 4 ise terörizm ile sosyal değişkenler arasındaki korelasyon bağlantılarını sunmaktadır. 


\begin{tabular}{|c|c|c|c|c|c|c|c|c|c|c|c|c|c|c|}
\hline \multirow[t]{2}{*}{ Değişken } & \multirow{2}{*}{$\begin{array}{c}\text { Korelasyon } \\
\text { İlişkileri }\end{array}$} & \multirow[t]{2}{*}{ Terör } & \multirow[t]{2}{*}{ Gelir } & \multirow{2}{*}{ Nüfus } & \multicolumn{4}{|c|}{ Eğitim } & \multirow[t]{2}{*}{ İşsizlik } & \multirow[t]{2}{*}{ Ticaret } & \multirow[t]{2}{*}{ Enflasyon } & \multirow{2}{*}{ Yoksulluk } & \multirow{2}{*}{ Eşitsizlik } & \multirow{2}{*}{ Tüketim } \\
\hline & & & & & İlkokul & Ortaokul & Lise & Üniversite & & & & & & \\
\hline Terör & $\begin{array}{l}\text { Korelasyon } \\
\text { t-İstatistiği } \\
\text { Olastllk }\end{array}$ & $\begin{array}{c}1.000 \\
- \\
-\end{array}$ & & & & & & & & & & & & \\
\hline Gelir & $\begin{array}{l}\text { Korelasyon } \\
\text { t-İstatistiği } \\
\text { Olasilik }\end{array}$ & $\begin{array}{l}0.032^{*} \\
1.793 \\
0.084\end{array}$ & $\begin{array}{c}1.000 \\
- \\
-\end{array}$ & & & & & & & & & & & \\
\hline Nüfus & $\begin{array}{l}\text { Korelasyon } \\
\text { t-İstatistiği } \\
\text { Olastlik }\end{array}$ & $\begin{array}{c}0.697^{* * * *} \\
8.639 \\
0.000\end{array}$ & $\begin{array}{c}0.336^{* * *} \\
3.176 \\
0.002\end{array}$ & $\begin{array}{c}1.000 \\
- \\
-\end{array}$ & & & & & & & & & & \\
\hline İlkokul & $\begin{array}{l}\text { Korelasyon } \\
\text { t-İstatistiği } \\
\text { Olasilik }\end{array}$ & $\begin{array}{c}-0.058^{*} \\
-1.698 \\
0.089\end{array}$ & $\begin{array}{c}0.322^{* * *} \\
3.030 \\
0.003\end{array}$ & $\begin{array}{l}0.142 \\
1.280 \\
0.204 \\
\end{array}$ & $\begin{array}{c}1.000 \\
- \\
-\end{array}$ & & & & & & & & & \\
\hline Ortaokul & $\begin{array}{l}\text { Korelasyon } \\
\text { t-İstatistiği } \\
\text { Olastlık }\end{array}$ & $\begin{array}{c}-0.261^{* *} \\
-2.407 \\
0.018\end{array}$ & $\begin{array}{c}0.515^{* * *} \\
5.350 \\
0.000\end{array}$ & $\begin{array}{l}0.149 \\
1.346 \\
0.182\end{array}$ & $\begin{array}{c}0.593^{* * *} \\
6.560 \\
0.000\end{array}$ & $\begin{array}{c}1.000 \\
- \\
-\end{array}$ & & & & & & & & \\
\hline Lise & $\begin{array}{l}\text { Korelasyon } \\
\text { t-İstatistiği } \\
\text { Olasilik }\end{array}$ & $\begin{array}{c}-0.326^{* * *} \\
-3.063 \\
0.003\end{array}$ & $\begin{array}{c}0.599^{* * *} \\
6.659 \\
0.000\end{array}$ & $\begin{array}{l}0.020 \\
0.179 \\
0.858 \\
\end{array}$ & $\begin{array}{c}0.432^{* * *} \\
4.258 \\
0.000\end{array}$ & $\begin{array}{c}0.770^{* * *} \\
10.747 \\
0.000\end{array}$ & $\begin{array}{c}1.000 \\
- \\
- \\
\end{array}$ & & & & & & & \\
\hline Üniversite & $\begin{array}{l}\text { Korelasyon } \\
\text { t-İstatistiği } \\
\text { Olasillk }\end{array}$ & $\begin{array}{c}-0.471^{* * *} \\
-3.070 \\
0.002\end{array}$ & $\begin{array}{c}0.647^{* *} \\
2.142 \\
0.035\end{array}$ & $\begin{array}{l}-0.005 \\
-0.049 \\
0.960\end{array}$ & $\begin{array}{l}0.060 \\
0.540 \\
0.590\end{array}$ & $\begin{array}{l}0.137 \\
1.237 \\
0.219\end{array}$ & $\begin{array}{l}0.185^{*} \\
1.680 \\
0.096\end{array}$ & $\begin{array}{c}1.000 \\
- \\
-\end{array}$ & & & & & & \\
\hline İşsizlik & $\begin{array}{l}\text { Korelasyon } \\
\text { t-İstatistiği } \\
\text { Olasilık }\end{array}$ & $\begin{array}{c}0.467^{* * * *} \\
4.700 \\
0.000 \\
\end{array}$ & $\begin{array}{c}-0.155^{*} \\
-1.702 \\
0.088 \\
\end{array}$ & $\begin{array}{l}0.169 \\
1.532 \\
0.129 \\
\end{array}$ & $\begin{array}{c}-0.026 \\
-0.239 \\
0.811 \\
\end{array}$ & $\begin{array}{c}-0.314^{* * * *} \\
-2.941 \\
0.004 \\
\end{array}$ & $\begin{array}{c}-0.436^{* * *} \\
-4.318 \\
0.000 \\
\end{array}$ & $\begin{array}{c}-0.546^{*} \\
-1.686 \\
0.094 \\
\end{array}$ & $\begin{array}{c}1.000 \\
- \\
- \\
\end{array}$ & & & & & \\
\hline Ticaret & $\begin{array}{l}\text { Korelasyon } \\
\text { t-İstatistiği } \\
\text { Olasilık }\end{array}$ & $\begin{array}{c}0.400^{* * * *} \\
3.886 \\
0.000 \\
\end{array}$ & $\begin{array}{c}0.236^{* *} \\
2.162 \\
0.033 \\
\end{array}$ & $\begin{array}{c}0.578^{* * * *} \\
6.296 \\
0.000 \\
\end{array}$ & $\begin{array}{l}0.181 \\
1.644 \\
0.104 \\
\end{array}$ & $\begin{array}{l}0.166 \\
1.501 \\
0.137 \\
\end{array}$ & $\begin{array}{l}0.081 \\
0.723 \\
0.471 \\
\end{array}$ & $\begin{array}{l}0.008 \\
0.071 \\
0.942\end{array}$ & $\begin{array}{l}0.100 \\
0.899 \\
0.371\end{array}$ & $\begin{array}{c}1.000 \\
- \\
-\end{array}$ & & & & \\
\hline Enflasyon & $\begin{array}{l}\text { Korelasyon } \\
\text { t-Istatistiği } \\
\text { Olastlık } \\
\end{array}$ & $\begin{array}{l}0.181^{*} \\
1.737 \\
0.086 \\
\end{array}$ & $\begin{array}{c}0.723^{* * *} \\
9.306 \\
0.000 \\
\end{array}$ & $\begin{array}{c}0.548^{* * *} \\
5.827 \\
0.000 \\
\end{array}$ & $\begin{array}{l}0.181 \\
1.644 \\
0.104 \\
\end{array}$ & $\begin{array}{c}0.363^{* * *} \\
3.473 \\
0.000 \\
\end{array}$ & $\begin{array}{c}0.487^{* * *} \\
4.968 \\
0.000 \\
\end{array}$ & $\begin{array}{c}0.508^{* *} \\
2.145 \\
0.034 \\
\end{array}$ & $\begin{array}{c}-0.232^{* *} \\
-2.128 \\
0.036 \\
\end{array}$ & $\begin{array}{c}0.268^{* *} \\
2.474 \\
0.015 \\
\end{array}$ & $\begin{array}{c}1.000 \\
- \\
- \\
\end{array}$ & & & \\
\hline Yoksulluk & $\begin{array}{l}\text { Korelasyon } \\
\text { t-İstatistiği } \\
\text { Olasllık }\end{array}$ & $\begin{array}{c}0.032^{* * * *} \\
4.716 \\
0.000\end{array}$ & $\begin{array}{c}-0.215^{*} \\
-1.960 \\
0.053\end{array}$ & $\begin{array}{l}0.080^{*} \\
1.682 \\
0.095\end{array}$ & $\begin{array}{c}-0.104 \\
-0.930 \\
0.355\end{array}$ & $\begin{array}{c}-0.106 \\
-0.916 \\
0.362\end{array}$ & $\begin{array}{c}-0.135 \\
-1.217 \\
0.227\end{array}$ & $\begin{array}{l}-0.157 \\
-0.515 \\
0.607\end{array}$ & $\begin{array}{l}0.057^{*} \\
1.705 \\
0.086\end{array}$ & $\begin{array}{c}-0.212^{*} \\
-1.932 \\
0.056\end{array}$ & $\begin{array}{l}0.097^{*} \\
1.795 \\
0.083\end{array}$ & $\begin{array}{c}1.000 \\
- \\
-\end{array}$ & & \\
\hline Eşitsizlik & $\begin{array}{l}\text { Korelasyon } \\
\text { t-Istatistiği } \\
\text { Olasilık }\end{array}$ & $\begin{array}{c}0.307^{* * *} \\
2.868 \\
0.005\end{array}$ & $\begin{array}{c}0.356^{* * *} \\
3.396 \\
0.001\end{array}$ & $\begin{array}{l}0.199^{*} \\
1.810 \\
0.074\end{array}$ & $\begin{array}{c}0.195^{*} \\
1.769 \\
0.080\end{array}$ & $\begin{array}{l}0.183^{* *} \\
2.627 \\
0.011\end{array}$ & $\begin{array}{c}0.157^{* * * *} \\
4.577 \\
0.000\end{array}$ & $\begin{array}{c}0.135^{*} \\
1.815 \\
0.072\end{array}$ & $\begin{array}{c}0.350^{* * *} \\
3.323 \\
0.001\end{array}$ & $\begin{array}{c}-0.069 \\
-0.617 \\
0.538 \\
\end{array}$ & $\begin{array}{l}0.263^{* *} \\
2.430 \\
0.017\end{array}$ & $\begin{array}{c}0.629^{* * *} \\
7.207 \\
0.000\end{array}$ & $\begin{array}{c}1.000 \\
- \\
- \\
\end{array}$ & \\
\hline Tüketim & $\begin{array}{l}\text { Korelasyon } \\
\text { t-İstatistiği } \\
\text { Olasllık } \\
\end{array}$ & $\begin{array}{c}-0.226^{* *} \\
-2.065 \\
0.042 \\
\end{array}$ & $\begin{array}{l}0.742^{* * *} \\
9.839 \\
0.000 \\
\end{array}$ & $\begin{array}{c}-0.294^{* * *} \\
-2.736 \\
0.007 \\
\end{array}$ & $\begin{array}{l}0.332^{* * *} \\
3.128 \\
0.002 \\
\end{array}$ & $\begin{array}{c}0.586^{* * * *} \\
6.432 \\
0.000 \\
\end{array}$ & $\begin{array}{c}0.694^{* * *} \\
8.577 \\
0.000 \\
\end{array}$ & $\begin{array}{l}0.720^{* * * *} \\
8.976 \\
0.000 \\
\end{array}$ & $\begin{array}{c}-0.488^{* * *} \\
-4.982 \\
0.000 \\
\end{array}$ & $\begin{array}{l}0.235^{* *} \\
2.149 \\
0.034 \\
\end{array}$ & $\begin{array}{c}-0.615^{* * *} \\
-6.933 \\
0.000 \\
\end{array}$ & $\begin{array}{c}-0.065 \\
-0.584 \\
0.560 \\
\end{array}$ & $\begin{array}{l}-0.206^{*} \\
1.873 \\
0.064 \\
\end{array}$ & $\begin{array}{c}1.000 \\
- \\
- \\
\end{array}$ \\
\hline
\end{tabular}




\begin{tabular}{|c|c|c|c|c|c|c|c|c|c|c|c|c|c|}
\hline Değişken & $\begin{array}{c}\text { Korelasyon } \\
\text { İlișkileri }\end{array}$ & Terör & Umut & Mutluluk & Suç & Demokrasi & Etnik & Kıyı & Yerleşik & Çatışma & Coğrafya & Uzaklık & Kent \\
\hline Terör & $\begin{array}{l}\text { Korelasyon } \\
\text { t-İstatistiği } \\
\text { Olasllik }\end{array}$ & $\begin{array}{c}1.000 \\
- \\
-\end{array}$ & & & & & & & & & & & \\
\hline Umut & $\begin{array}{l}\text { Korelasyon } \\
\text { t-Istatistiği } \\
\text { Olasllik }\end{array}$ & $\begin{array}{c}-0.208^{*} \\
-1.897 \\
0.061 \\
\end{array}$ & $\begin{array}{c}1.000 \\
- \\
- \\
\end{array}$ & & & & & & & & & & \\
\hline Mutluluk & $\begin{array}{l}\text { Korelasyon } \\
\text { t-İstatistiği } \\
\text { Olasillk }\end{array}$ & $\begin{array}{c}-0.097^{*} \\
-1.739 \\
0.084\end{array}$ & $\begin{array}{c}0.594^{* * *} \\
6.575 \\
0.000\end{array}$ & $\begin{array}{c}1.000 \\
- \\
- \\
\end{array}$ & & & & & & & & & \\
\hline Suç & $\begin{array}{l}\text { Korelasyon } \\
\text { t-İstatistiği } \\
\text { Olasillk }\end{array}$ & $\begin{array}{c}0.546^{* * *} \\
5.800 \\
0.000\end{array}$ & $\begin{array}{c}-0.123^{*} \\
-1.700 \\
0.087 \\
\end{array}$ & $\begin{array}{c}-0.213^{*} \\
-1.939 \\
0.056 \\
\end{array}$ & $\begin{array}{c}1.000 \\
- \\
- \\
\end{array}$ & & & & & & & & \\
\hline Demokrasi & $\begin{array}{l}\text { Korelasyon } \\
\text { t-İstatistiği } \\
\text { Olasillk }\end{array}$ & $\begin{array}{c}0.001^{*} \\
1.690 \\
0.092 \\
\end{array}$ & $\begin{array}{l}0.173 \\
1.561 \\
0.122 \\
\end{array}$ & $\begin{array}{c}0.237^{* *} \\
2.171 \\
0.032 \\
\end{array}$ & $\begin{array}{c}-0.248^{* *} \\
-2.277 \\
0.025 \\
\end{array}$ & $\begin{array}{c}1.000 \\
- \\
- \\
\end{array}$ & & & & & & & \\
\hline Etnik & $\begin{array}{l}\text { Korelasyon } \\
\text { t-İstatistiği } \\
\text { Olasillk }\end{array}$ & $\begin{array}{c}-0.536^{* * *} \\
-5.645 \\
0.000\end{array}$ & $\begin{array}{c}0.362^{* * *} \\
3.453 \\
0.000\end{array}$ & $\begin{array}{l}0.098 \\
0.878 \\
0.382\end{array}$ & $\begin{array}{l}0.164 \\
1.486 \\
0.141 \\
\end{array}$ & $\begin{array}{c}0.267^{* *} \\
2.470 \\
0.015\end{array}$ & $\begin{array}{c}1.000 \\
- \\
-\end{array}$ & & & & & & \\
\hline Kıyı & $\begin{array}{l}\text { Korelasyon } \\
\text { t-İstatistiği } \\
\text { Olasillk } \\
\end{array}$ & $\begin{array}{c}0.038^{* * *} \\
3.345 \\
0.000 \\
\end{array}$ & $\begin{array}{c}-0.043 \\
-0.387 \\
0.699 \\
\end{array}$ & $\begin{array}{l}0.158 \\
1.425 \\
0.157 \\
\end{array}$ & $\begin{array}{c}0.336^{* * *} \\
3.175 \\
0.002 \\
\end{array}$ & $\begin{array}{l}0.129 \\
1.157 \\
0.250 \\
\end{array}$ & $\begin{array}{c}0.301^{* * *} \\
2.810 \\
0.006 \\
\end{array}$ & $\begin{array}{c}1.000 \\
- \\
- \\
\end{array}$ & & & & & \\
\hline Yerleşik & $\begin{array}{l}\text { Korelasyon } \\
\text { t-İstatistiği } \\
\text { Olasillk }\end{array}$ & $\begin{array}{c}0.075^{* *} \\
2.170 \\
0.027\end{array}$ & $\begin{array}{c}-0.041 \\
-0.367 \\
0.714\end{array}$ & $\begin{array}{l}0.141 \\
1.268 \\
0.208\end{array}$ & $\begin{array}{c}0.230^{* *} \\
2.108 \\
0.038\end{array}$ & $\begin{array}{c}-0.424^{* * *} \\
-4.161 \\
0.000\end{array}$ & $\begin{array}{c}0.146^{*} \\
1.880 \\
0.061\end{array}$ & $\begin{array}{l}0.180 \\
1.633 \\
0.106\end{array}$ & $\begin{array}{c}1.000 \\
- \\
-\end{array}$ & & & & \\
\hline Çatışma & $\begin{array}{l}\text { Korelasyon } \\
\text { t-İstatistiği } \\
\text { Olasillk }\end{array}$ & $\begin{array}{c}-0.341^{* * *} \\
-3.231 \\
0.001 \\
\end{array}$ & $\begin{array}{c}-0.418^{* * *} \\
-4.090 \\
0.000 \\
\end{array}$ & $\begin{array}{c}-0.147 \\
-1.325 \\
0.189 \\
\end{array}$ & $\begin{array}{c}-0.194^{*} \\
-1.761 \\
0.082 \\
\end{array}$ & $\begin{array}{c}-0.418^{* * *} \\
-4.096 \\
0.000 \\
\end{array}$ & $\begin{array}{c}0.690^{* * *} \\
8.489 \\
0.000 \\
\end{array}$ & $\begin{array}{c}0.370^{* * *} \\
3.548 \\
0.000 \\
\end{array}$ & $\begin{array}{l}0.114 \\
1.021 \\
0.310 \\
\end{array}$ & $\begin{array}{c}1.000 \\
- \\
- \\
\end{array}$ & & & \\
\hline Coğrafya & $\begin{array}{l}\text { Korelasyon } \\
\text { t-Istatistiği } \\
\text { Olasillk }\end{array}$ & $\begin{array}{c}0.303^{* * *} \\
2.835 \\
0.005 \\
\end{array}$ & $\begin{array}{c}-0.357^{* * *} \\
-3.452 \\
0.001 \\
\end{array}$ & $\begin{array}{c}-0.253^{* *} \\
-2.325 \\
0.022 \\
\end{array}$ & $\begin{array}{c}0.203^{*} \\
1.844 \\
0.068 \\
\end{array}$ & $\begin{array}{c}-0.458^{* * *} \\
-4.587 \\
0.000\end{array}$ & $\begin{array}{c}0.625^{* * *} \\
7.118 \\
0.000 \\
\end{array}$ & $\begin{array}{c}0.429^{* * *} \\
4.226 \\
0.000 \\
\end{array}$ & $\begin{array}{c}0.106^{*} \\
1.687 \\
0.093 \\
\end{array}$ & $\begin{array}{c}0.824^{* * *} \\
12.948 \\
0.000\end{array}$ & $\begin{array}{c}1.000 \\
- \\
- \\
\end{array}$ & & \\
\hline Uzaklık & $\begin{array}{l}\text { Korelasyon } \\
\text { t-Ístatistiği } \\
\text { Olasilık }\end{array}$ & $\begin{array}{c}-0.238^{* *} \\
-2.184 \\
0.031\end{array}$ & $\begin{array}{c}0.194^{*} \\
1.762 \\
0.081\end{array}$ & $\begin{array}{c}0.191^{* * *} \\
4.818 \\
0.000\end{array}$ & $\begin{array}{c}-0.332^{* * *} \\
-3.128 \\
0.002\end{array}$ & $\begin{array}{c}0.574^{* * *} \\
6.242 \\
0.000\end{array}$ & $\begin{array}{c}-0.633^{* * *} \\
-7.284 \\
0.000\end{array}$ & $\begin{array}{c}-0.497^{* * *} \\
-5.102 \\
0.000\end{array}$ & $\begin{array}{c}-0.200^{*} \\
-1.816 \\
0.073\end{array}$ & $\begin{array}{c}-0.711^{* * *} \\
-9.011 \\
0.000\end{array}$ & $\begin{array}{c}-0.767 \\
-0.620 \\
0.536\end{array}$ & $\begin{array}{c}1.000 \\
- \\
-\end{array}$ & \\
\hline Kent & $\begin{array}{l}\text { Korelasyon } \\
\text { t-İstatistiği } \\
\text { Olastlık }\end{array}$ & $\begin{array}{l}0.120 \\
1.080 \\
0.283\end{array}$ & $\begin{array}{c}-0.173 \\
-1.564 \\
0.121\end{array}$ & $\begin{array}{c}-0.297^{* * *} \\
-2.771 \\
0.006\end{array}$ & $\begin{array}{c}0.531^{* * *} \\
5.576 \\
0.000\end{array}$ & $\begin{array}{c}0.325^{* * *} \\
3.060 \\
0.003\end{array}$ & $\begin{array}{l}0.149 \\
1.339 \\
0.184\end{array}$ & $\begin{array}{c}-0.218^{* *} \\
-1.987 \\
0.050\end{array}$ & $\begin{array}{c}-0.270^{* *} \\
-2.493 \\
0.014\end{array}$ & $\begin{array}{c}-0.132 \\
-1.187 \\
0.238\end{array}$ & $\begin{array}{c}-0.054 \\
-0.485 \\
0.628\end{array}$ & $\begin{array}{c}0.231^{* *} \\
2.115 \\
0.037\end{array}$ & $\begin{array}{c}1.000 \\
- \\
-\end{array}$ \\
\hline
\end{tabular}

Not: Tabloda yer alan ${ }^{* * *},{ }^{* *}$ ve ${ }^{*}$ işaretleri ilgili katsayının sırasıyla $\% 1, \% 5$ ve $\% 10$ önem düzeyinde anlamlı olduğunu yansıtmaktadır. 
Tablo 3 ve Tablo 4'de sunulan korelasyon katsayıları incelendiğinde, Kent değişkeni dışındaki her değişkenin Terör değişkeni ile belirli bir anlamlılık düzeyinde korelasyon ilişkisine sahip olduğu ve bu ilişkilerin de beklentileri karşılar nitelikteki katsayı işaretlerini bünyesinde barındırdığı görünmektedir. Makroekonomik değişkenler bazında ilişkiler dikkate alındığında, gelir seviyesinin düşük bir anlamlılık düzeyinde bile olsa terörizm ile pozitif yönlü olarak bağlantılı olduğu sonucu ortaya çıkmaktadır. Nüfus değişkeninin Yoksulluk değişkeni ile istatistiki bakımdan anlamlı ve pozitif yönlü bir korelasyon ilişkisi içinde olması, nüfus ve yoksulluğun birbirlerini etkilemek suretiyle terörizm olgusuna yol açabileceği şeklinde ifade edilebilmektedir. Terör belâsı ile eğitim düzeyi arasında ortaya çıkan negatif yönlü korelasyon bulguları, bir üst eğitim basamağına geçildikçe terör olgusunun azalabileceğini, buna karşın eğitim seviyesi azaldıkça da terörizmin ivme kazanabileceğini gözler önüne sermektedir. Türkiye ekonomisinin en büyük problemlerinden biri olan işsizlik, terörizmin tetiklenmesi bakımından da kendisini ön plana çıkarabilmektedir. İşsizliğin artmasına bağlı olarak gelir düzeyinin azalabileceğini yansıtan korelasyon sonuçları, ekonomik yoksunluk argümanına adeta atıfta bulunmakta ve Gelir değişkeni ile bağlantılı olabilecek şekilde terörizme yol açabilmektedir. Ticaret ve dışa açıklık hacminin gelir düzeyi ile ilintili olabileceği ve ticaret eğilimine paralel bir biçimde kendini göstermesi muhtemel olan ve ivme kazanabilen gelire bağlı olarak terörizmin tetiklenebileceği söylenebilir. Geleceği belirsizleştiren, gelir dağılımında adaleti bozarak yoksulluğu artıran ve gelir pastasını bazı sosyal sınıflar lehine büyüten enflasyon düzeyi, ifade edilen olgulardan hareketle terörizme kaynaklık edebilen bir başka unsur olarak karşımıza çıkmaktadır. Toplumsal düzeni bozan ve sosyal adalet duygularını zedeleyen yoksulluk ve eşitsizlik düzeyleri, terörizmin beslendiği bir başka kanal olarak görülebilmektedir. Refahın öncü göstergelerinden biri olan tüketim seviyesi ile terörizm arasında negatif yönlü bir korelasyon ilişkisinin ortaya çıkması, tüketim seviyesindeki değişimin toplumsal yapının ve huzurun bozulması yönündeki baskıları azaltabileceğini yansitabilmektedir.

Geleceğe yönelik olumlu beklentilerin umut ve mutluluk düzeylerini etkileyerek terör eylemlerinin negatif yönlü olarak değişmesine yol açabileceğinin gösterildiği Tablo 4, terörizmin toplumsal umut ve mutluluk düzeylerini negatif yönlü olarak etkilediğini de göstermektedir. Benzer bir durum, Suç değişkeni itibariyle de kendisini göstermekte ve 
toplumsal suç işleme düzeyindeki değişim ile terörizm arasında negatif yönlü ve güçlü korelasyon bağlantıları olduğu anlaşılabilmektedir. Demokrasi değişkeni ile Terör değişkeninin düşük bir anlamlılık düzeyinde bile olsa pozitif yönlü bir korelasyon ilişkisi içinde olması, siyasal zeminin terörizme dayanak noktası oluşturabileceği izlenimini akla getirebilmektedir. Terör değişkeni ile Etnik değişkeni arasındaki negatif yönlü bir korelasyon bağlantısının saptanması, etnik ayrışma düzeyindeki bir değişime paralel olarak terörizmin güçlü bir biçimde tepki verebileceği şeklinde yorumlanmalıdır. Diğer taraftan, Türkiye'de terör eylemlerinin genellikle kıyı kesiminden uzak Doğu ve Güneydoğu Anadolu bölgelerinde kümelenme eğilimi içinde olduğu gözlenmektedir. Bu eğilimin ekonometrik anlamda geçerli olup olmadığını test edebilmek amacıyla Kıyı değişkeni analizlere dâhil edilmiş ve kıyı kesimlerinden uzaklaştıkça terör eylemleri sıklığının öngörüldüğü şekilde pozitif yönlü olarak değiştiği görülmüştür. Yerleşik değişkeni ile Suç ve Terör değişkenleri arasında pozitif yönlü ve istatistiki bakımdan anlamlı korelasyon ilişkilerinin bulunması, yerleşik mobilitesine bağlı olarak suç işleme potansiyelinin ve dolayısıyla da terör eylemlerinin değişebilme olasılığının söz konusu olabileceğini yansıtmaktadır. Diğer taraftan Tablo 4, Çatışma ve Terör değişkenleri arasında istatistiki bakımdan yüksek dereceli bir anlamlılık düzeyi çerçevesinde negatif yönlü korelasyon bağlantılarının varlığını ortaya koymaktadır. Birbirlerini teyit edebilmeleri amacıyla modelleme sürecine dâhil edilen Coğrafya ve Uzaklık değişkenleri, terör eylemlerinin yoğun olarak gerçekleştiği yerlere sınır komşusu olan illerde terör faaliyetlerinin hız kazanabileceğini, bir diğer ifadeyle terörizmin bulaşma etkisinin söz konusu olabileceğini yansıtmaktadır. Bu durum, Coğrafya değişkeni ile Terör değişkeni arasında anlamlı bir pozitif yönlü ilişkinin varlığı yoluyla gösterilmiştir. Diğer taraftan, terörizm olgusu ile en çok muhatap olan il merkezine (Hakkâri) km bazında olan uzaklık arttıkça terörizmin bulaşma etkisinin de ortadan kalkma ihtimalinin artabileceği, yani Uzaklık değişkeni ile Terör değişkeni arasında negatif yönlü ve anlamlı bir korelasyon ilişkisinin geçerli olduğu söylenebilir.

Çalışmanın bu kısmında; Türkiye'deki 80 ilin, 2014 yılı itibariyle en yüksek kişi başına katma değere sahip il olan İstanbul'a (2014 yılı öngörü değeri itibariyle kişi başına gayrisafi katma değer 18318 ABD doları) yakınsayıp yakınsamadığı ve terörizmin yakınsama süreci üzerindeki etkisi (7) numaralı regresyon eşitliğinden hareketle hesaplanmıştır. (7) numaralı regresyon eşitliği, bütün illerin aynı durağan durumda dengeye geldiğini zımnen kabul etse bile, 
GWR analizi yardımıyla ilgili kısıt süreci ağırlık matrisleri kullanılarak aşılmış ve (13) numaralı regresyon denklemi yardımıyla çözümleme sürecine gidilmiştir:

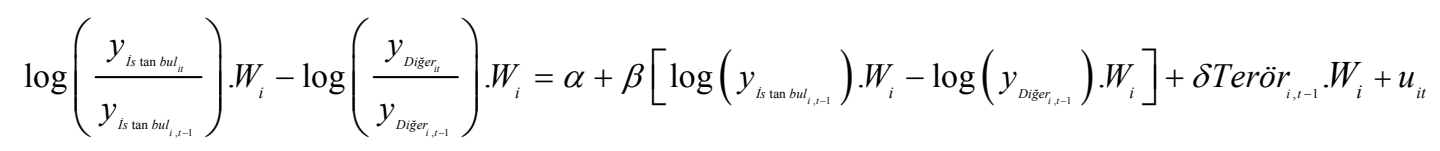

(13) numaralı regresyon eşitliğinde yer alan $W_{i}, i$ lokasyonuna ait coğrafi ağırlık değişkenini yansıtmaktadır. Tablo 5, yakınsama analizi test sonuçlarını ve Şekil 1 ise başlangıç dönemi kişi başına düşen gelir katsayılarının $\left(\beta\left[\log \left(y_{\text {Istanbul }_{i, t-1}}\right)-\log \left(y_{\text {Diğerit,-1 }_{i, 1}}\right)\right]\right)$ mekânsal dağılımını yansıtmaktadır.

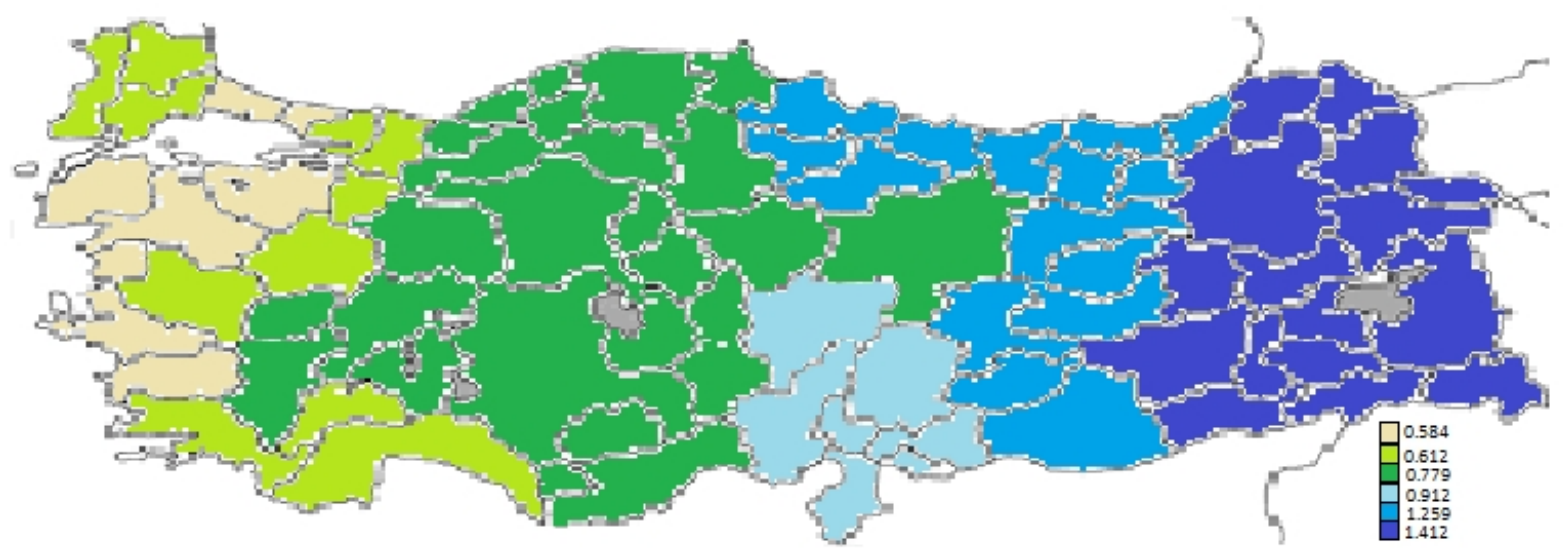

Şekil 1: Başlangıç Dönemi Kişi Başına Düşen Gelir Katsayılarının Mekânsal Dağılımı 


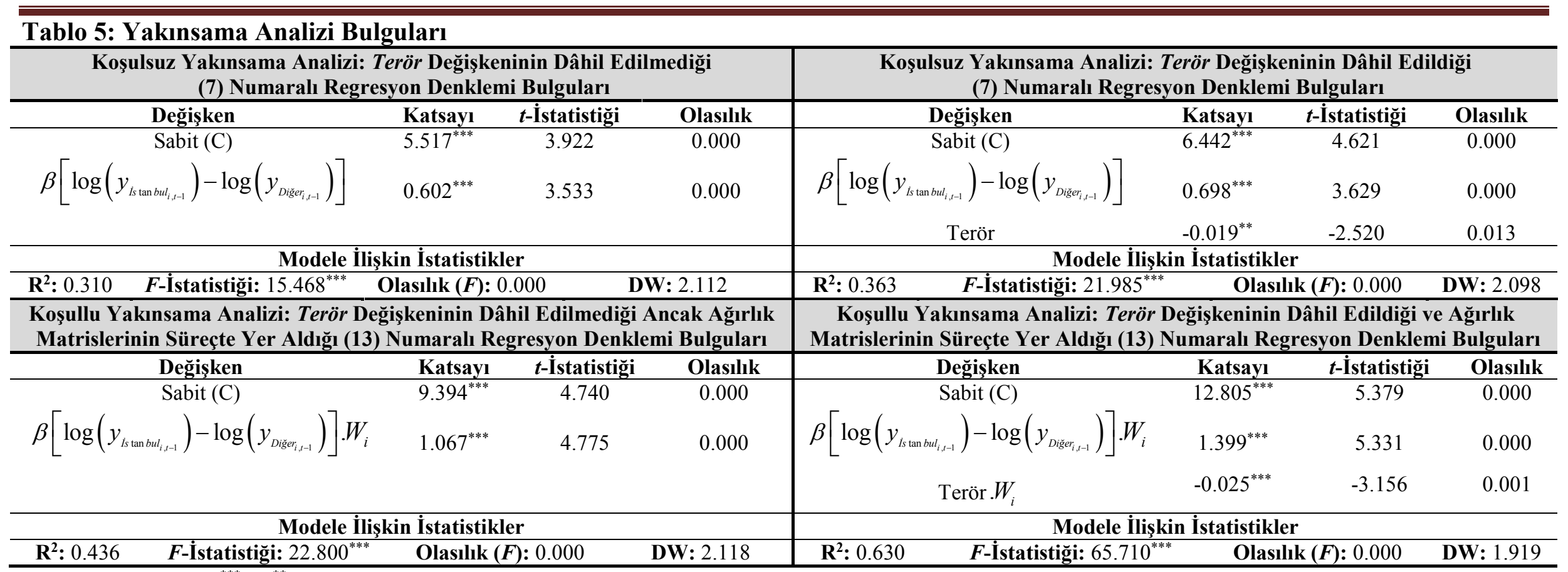

Not: Tabloda yer alan ${ }^{* * *}$ ve $^{* *}$ işaretleri sırasıyla ilgili değişkenin $\% 1$ ve $\% 5$ önem düzeyinde anlamlı olduğunu yansıtmaktadır. 
Her ilin yakınsama katsayılarının mekânsal dağılımı, Türkiye'de ıraksama sürecinin baskın olduğunu yansıtmakta ve ıraksama katsayılarının 0.584 ve 1.412 bandında dalgalandığını göstermektedir. Bu sonuç, Batı ve Doğu bölgelerinde bulunan iller arasındaki yapısal farklılığın büyük boyutlarda olduğunu yansıtmaktadır. Dolayısıyla, Tablo 5 'den de izlenebileceği üzere, Türkiye'de bulunan iller arasında 1raksama sürecinin kendini gösterdiği net olarak ifade edilebilmektedir. Ayrıca Şekil 1, ekonomik anlamda daha az gelişmiş olan Doğu ve Güneydoğu bölgelerinde bulunan illerin, Batı ve Güneybatı bölgelerinde bulunan illere kıyasla daha yüksek parametre tahminleri sergilediğini de vurgulamak olasıdır.

Tablo 5'de yer alan ve Terör değişkeninin yer almadığı koşulsuz yakınsama analizi bulguları, İstanbul ile diğer iller arasında güçlü bir ıraksama sürecinin ( $\beta$ katsayısının pozitif olarak 0.602 değerini alması dolayısıyla) söz konusu olduğunu, bir diğer ifadeyle İstanbul ile diğer illerin gelir düzeyi arasında büyük bir uçurumun ortaya çıktığını gözler önüne sermektedir. Modelin bir bütün olarak anlamlı olması ve otokorelasyon problemini bünyesinde barındırmaması, tutarlı sonuçların elde edildiğinin bir göstergesi olarak değerlendirilebilir. Bununla birlikte, modelin belirlilik katsayısının nispeten düşük olması, modele ilave değişkenlerin eklenmesi hususunu gündeme getirmektedir. Söz konusu bu çalışma kapsamında gerçekleştirilen yakınsama analizinin dikkate alınmasının temel nedeni, terörizmin yakınsama ya da ıraksama dinamizmi üzerindeki etkilerini incelemek olduğundan dolayı, Terör değişkeni koşulsuz yakınsama analizine dâhil edilmiş ve (7) numaralı regresyon eşitliği yeniden sınanmıştır. Bu kapsamda ortaya konan analiz bulguları, birinci aşamada gerçekleştirilen koşulsuz yakınsama analiz bulgularını teyit eden nitelikte sonuçlar elde edilmesini sağlamıştır. Bir başka deyişle, İstanbul ile diğer iller arasında yeniden ıraksama sürecinin ( $\beta$ katsayısının pozitif olarak 0.698 değerini alması dolayısıyla) kendini gösterdiği belirtilmiştir. Bununla birlikte, Terör değişkeninin sistemde olduğu koşulsuz yakınsama analiz bulguları, Türkiye'de yaşanan terör eylemlerinin iller arasındaki ıraksama sürecinin boyutlarını artırdığını yansıtmış ( $0.698>0.602$ olması nedeniyle) ve terörizmin gelir düzeyi üzerinde negatif yönlü ve istatistiki bakımdan anlamlı bir etkisinin olduğunu ortaya koymuştur. Diğer taraftan, Terör değişkeninin dâhil edildiği koşulsuz yakınsama modelinin bir bütün olarak daha yüksek bir anlamlılık düzeyine sahip olması ve otokorelasyon problemine sahne olmaması, etkin bir çözümleme sürecinin gerçekleştirilebildiği izlenimi yaratmaktadır. Ayrıca, ilk modele kıyasla daha yüksek 
bir belirlilik katsayısının elde edilmesi, Terör değişkeninin modelleme sürecinde önemli bir etkiye sahip olduğunu yansıtmakla birlikte, nispeten düşük düzeyde olduğu öne sürülebilen belirlilik katsayısı dolayısıyla farklı bir çözümleme tekniğine ihtiyaç duyulduğunu da ortaya koymaktadir.

Belirlilik katsayısının nispeten düşük olması şeklinde ifade edilen sorunun giderilebilmesi amacıyla koşullu yakınsama analizlerinden yararlanılmış ve bulgular Tablo 5'de gösterilmiştir. Koşulsuz yakınsama tekniğinin ortaya koyduğu katı varsayımdan ${ }^{7}$ kurtulabilmek adına modelin bağımsız değişkeni olan $\beta$ katsayısı ya da bu katsayıya konu olan Gelir ve Terör değişkenleri, GWR analiz tekniği yardımıyla belirlenen terör ağırlıklandırma katsayısı kullanılarak ağırlıklandırılmış ve dolayısıyla her ilin farklı bir durağan durumda dengeye geldiği ortaya konmuştur. Ağırlıklandırma birimi olarak Terör değişkeni baz alınmıştır. Bu değişkenin dikkate alınmasının temel nedeni, terör faaliyetlerinin yakınsama süreci üzerindeki etkilerinin saptanmaya çalışılmasından ileri gelmektedir. İfade edilen işleyiş mekanizmasından hareketle ilk olarak Terör değişkeninin dikkate alınmadığı (13) numaralı koşullu regresyon analizi çözümlenmiştir. Terör ağırlıklandırma katsayısı kullanılarak ağırlıklandırılan $\beta$ katsayısı, istatistiki bakımdan anlamlı ve güçlü bir pozitif yönlü ilişkinin varlığını ortaya koymuştur. Bu durum, İstanbul ile diğer iller arasında 1raksama sürecinin yaşandığı şeklinde yorumlanabilmektedir ( $\beta$ katsayısının pozitif olarak 1.067 değerini alması dolayısıyla). Bu noktada dikkate alınması gereken temel nokta ise $\beta$ katsayı büyüklükleridir. Analiz sonuçlarından rahatlıkla görülebileceği üzere, ağırlıklandırma katsayısının söz konusu olduğu koşullu $\beta$ katsayısı (1.067), böyle bir ağırlıklandırmanın olmadığı koşulsuz $\beta$ katsayısına (0.602) kıyasla oldukça yüksektir. Bu sonuç, ıraksama süreci üzerinde terörizmin dolaylı şiddetlendirici etkisinin oldukça baskın olduğunu kanıtlar niteliktedir. Bununla birlikte, analiz sonuçlarının bir bütün olarak anlamlı olması ve otokorelasyon sorununa kaynaklık etmemesi, tutarlı sonuçların elde edildiği şeklinde yorumlanabilir. Terör ağırlıklandırma katsayısının model çözümlemelerine eklenmesine bağlı olarak belirlilik katsayısının 0.310'dan 0.436'ya yükselmesi de analizler ile ilgili önemli bir ipucu niteliğindendir. Terörizmin koşullu yakınsama süreci üzerindeki dolaysız etkisi ise Terör değişeninin analizlere dâhil edilmesi

\footnotetext{
${ }^{7}$ Yakınsama sürecinde bütün illerin aynı yapısal özelliklere sahip olduğu ve dolayısıyla bütün illerin aynı durağan durumda dengeye geldiği varsayımıdır.
} 
yoluyla saptanmış ve yine her iki değişken ağırlıklandırma katsayısı kullanılarak ağırlıklandırılmıştır. Analiz sonuçları, terörizme bağlı olarak İstanbul ile diğer iller arasındaki ıraksama sürecinin şiddetlendiğini göstermiş ve $\beta$ katsayısı istatistiki bakımdan anlamlı ve güçlü bir pozitif yönlü ilişkiyi ortaya çıkarmıştır. Bu bulgu, iller arasında 1raksama olgusunun kendini gösterdiği şeklinde yorumlanabilir ( $\beta$ katsayısının pozitif olarak 1.399 değerini alması dolayısıyla). Bununla birlikte, Terör değişkeninin sistemde olduğu koşullu yakınsama analiz bulguları, Türkiye'de yaşanan terör eylemlerinin iller arasındaki ıraksama sürecinin boyutlarını artırdığını yansıtmış (1.399>1.067 olması nedeniyle) ve terörizmin gelir düzeyi üzerinde negatif yönlü ve istatistiki bakımdan anlamlı bir etkisinin olduğunu ortaya koymuştur. Yeni modelden elde edilen $\beta$ katsayısının (1.399), Terör değişkeninin sisteme dâhil edildiği ancak ağırlıklandırmanın söz konusu olmadığı koşulsuz modelin $\beta$ katsayısına (0.698) kıyasla oldukça yüksek olması, terörizmin tahrip edici gücünü bir kez daha yansıtmaktadır. Benzer şekilde, koşullu modelde Terör değişkeninin gelir düzeyi üzerindeki negatif yönlü etkisi 0.025), terör ağırlıklandırma katsayısının dikkate alınmadı̆̆ı koşulsuz modeldeki Terör değişkeninin katsayısına (-0.019) kıyasla daha yüksek ve istatistiki bakımdan daha güçlüdür. Bu durum, ağırlıklandırma katsayısı ile birleştiğinde terörizmin gelir ve refah düzeyi üzerindeki olumsuz etkisini gözler önüne sermektedir. Benzer şekilde, Terör değişkeninin ve ağırlıklandırma prosedürünün dikkate alındığı koşullu modelin bir bütün olarak anlamlı olması ve otokorelasyon sorununu bünyesinde barındırmaması dolayısıyla üstün bir model olduğu vurgulanabilmektedir. Dikkati çeken temel nokta ise, belirlilik katsayısının 0.630 gibi daha yüksek bir değer olarak saptanmasıdır ki, bu durum koşullu yakınsama sürecinin başarı ile sonuçlandırıldığı anlamına gelebilecek ve düşük belirlilik katsayısı probleminden modelin arındırıldığı şeklinde yorumlanabilecektir.

Oluşturulan dört yakınsama modelinin niteliğinin, birinciden sonuncuya doğru gidildikçe arttığı görülmektedir. Bu durum, kısıtlayıcı varsayımdan kurtulmanın ve modele etki edebilecek en temel değişkenin analizlere dâhil edilmesi nedeniyle ortaya çıkmıștır. Dolayısıyla, dört yakınsama modeli itibariyle birbirini destekleyen sonuçlara ulaşıldığını savunmak mümkündür.

Çalışmanın bu kısmında, Türkiye'de terörizmin sosyo-ekonomik belirleyicilerinin incelenebilmesi amacıyla GWR analizinden yararlanılmıştır. $\mathrm{Bu}$ amaç doğrultusunda 
hazırlanan Tablo 6 ve Tablo 7 sırasıyla terörizmin makroekonomik ve sosyal belirleyicilerine ilişkin analiz bulgularını ve Şekil 2 ise Terör değişkeninin katsayısına ait mekânsal dağılımı yansıtmaktadır. Analiz bulguları, karşılaştırma yapabilmek amacıyla hem OLS (global katsayılar) hem de GWR (yerel katsayılar) model tahmin sonuçlarını bir arada göstermektedir.

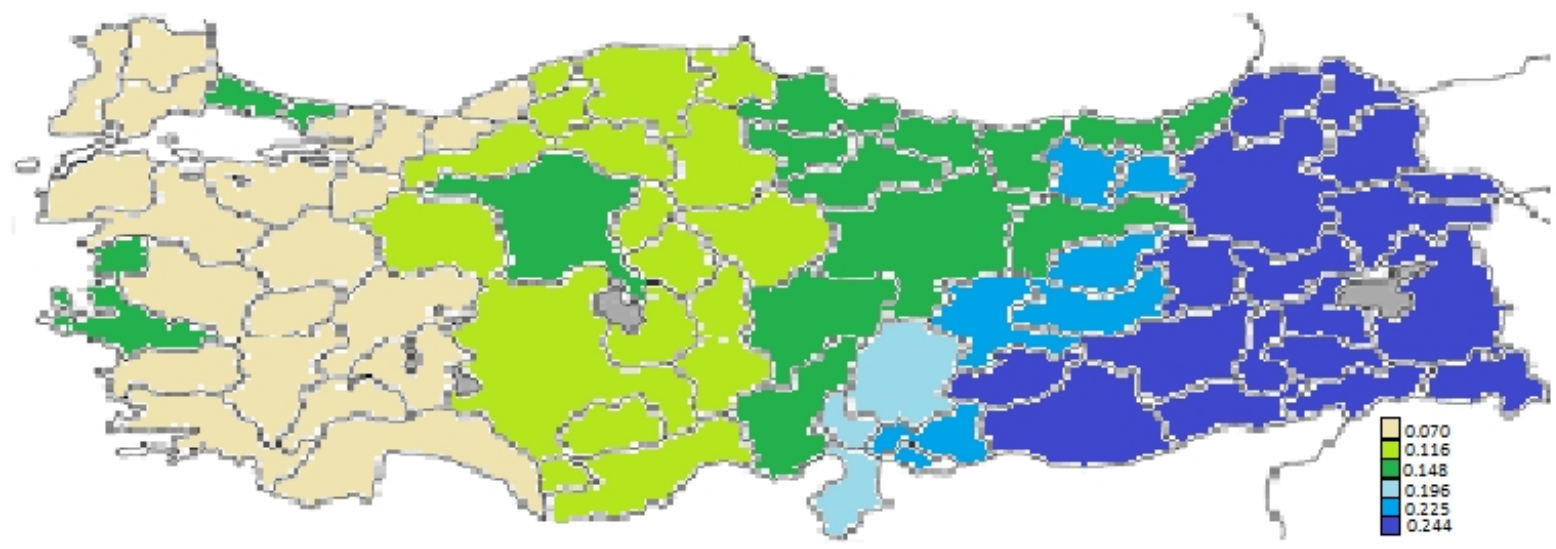

Şekil 2: Başlangıç Dönemi Terör Katsayılarının Mekânsal Dağılımı

Terör değişkenin geçmiş dönem değerlerinin cari dönem terör faaliyetleri üzerindeki etkilerinin gösterildiği Şekil 2, terörizmin geçmiş dönem değerlerinin 0.070 ve 0.244 bandında dalgalandığını göstermektedir. Şekil 2, Batı ve Doğu bölgelerinde bulunan illerde terör eylemlerinin şiddetini yansıtması bakımından önemli bir gösterge niteliğindedir. Terör değişkeninin geçmiş dönem değerlerinin mekânsal dağılımı, Türkiye'nin Batı bölgelerinde bulunan illerine kıyasla, Doğu ve Güneydoğu illerinde yaşanan terör eylemlerinin geçmiş dönemdeki boyutlarının, cari dönem terör eylemleri üzerindeki pozitif yönlü etkilerinin daha baskın olduğunu yansıtmaktadır. Tablo 6 ve Tablo 7'de sunulan makroekonomik ve sosyal değişkenlerle birleştiğinde, Doğu ve Güneydoğu bölgelerinde bulunan illerde kendini gösteren yüksek nüfus artışı, düşük eğitim düzeyi, yüksek oranlı işsizlik, fiyatlardaki hızlı artış eğilimi, yoksulluk ve eşitsizlik olguları bu süreci destekler bir nitelik taşımaktadır. Geleceğe yönelik beklentilerin daha düşük olduğu Doğu ve Güneydoğu bölgelerindeki iller, suç işleme eğiliminin yüksek olduğu, etnik ayrımcılığın kendini fazlasıyla hissettirdiğgi, tamamen haklı gerekçelerle yürütülen askeri operasyonların varlığı ve coğrafi etkenlerden dolayı da terörizme sıklıkla maruz kalabilmektedir. 


\begin{tabular}{|c|c|c|c|c|c|c|c|}
\hline \multicolumn{2}{|c|}{ Değișkenler } & Minimum & \%25'lik Kartil & GWR & OLS & $\% 75$ 'lik Kartil & Maksimum \\
\hline \multicolumn{2}{|c|}{ Sabit (C) } & -84.134 & -84.114 & $-71.863^{* * *}(0.000)$ & $-19.653(0.379)$ & -62.670 & -60.116 \\
\hline \multicolumn{2}{|c|}{ Gelir } & 0.001 & 0.003 & $0.004^{* * *}(0.000)$ & $0.006^{*}(0.094)$ & 0.008 & 0.012 \\
\hline \multicolumn{2}{|c|}{ Gelir $^{2}$} & -8.075 & -8.018 & $-5.440^{* *}(0.024)$ & $-4.576^{*}(0.087)$ & -2.746 & -2.422 \\
\hline \multicolumn{2}{|c|}{ Nüfus } & $1.13 \mathrm{E}-06$ & $1.23 \mathrm{E}-06$ & $2.98 \mathrm{E}-06^{* * *}(0.000)$ & $3.03 \mathrm{E}-06^{* *}(0.022)$ & $5.46 \mathrm{E}-06$ & $5.71 \mathrm{E}-06$ \\
\hline \multirow{4}{*}{ 吉 } & İlkokul & -1.363 & -1.313 & $-0.636^{*}(0.074)$ & $-0.290(0.373)$ & -0.577 & -0.501 \\
\hline & Ortaokul & -2.311 & -2.270 & $-2.122^{* * *}(0.000)$ & $-1.647^{* *}(0.036)$ & -1.584 & -1.566 \\
\hline & Lise & -1.143 & -1.101 & $-0.747^{* *}(0.016)$ & $-0.678^{*}(0.067)$ & -0.650 & -0.629 \\
\hline & Üniversite & -0.844 & -0.801 & $-0.754^{* * *}(0.000)$ & $-0.001(0.496)$ & -0.687 & -0.652 \\
\hline \multicolumn{2}{|c|}{ İşsizlik } & 0.136 & 0.152 & $0.212^{* *}(0.037)$ & $0.453^{*}(0.066)$ & 0.521 & 0.550 \\
\hline \multicolumn{2}{|c|}{ Ticaret } & 2.468 & 2.492 & $2.934^{*}(0.071)$ & $1.260(0.711)$ & 3.210 & 3.244 \\
\hline \multicolumn{2}{|c|}{ Enflasyon } & 0.176 & 0.198 & $0.215^{* *}(0.046)$ & $0.261^{*}(0.082)$ & 1.023 & 1.049 \\
\hline \multicolumn{2}{|c|}{ Yoksulluk } & 1.345 & 1.367 & $1.841^{* * *}(0.001)$ & $1.922^{*}(0.092)$ & 2.222 & 2.251 \\
\hline \multicolumn{2}{|c|}{ Eşitsizlik } & 68.432 & 68.451 & $97.520^{* *}(0.032)$ & $116.914^{*}(0.069)$ & 202.945 & 202.964 \\
\hline \multicolumn{2}{|c|}{ Tüketim } & -3.581 & -3.557 & $-2.943^{* * *}(0.001)$ & $-2.742^{* *}(0.013)$ & -2.604 & -2.585 \\
\hline \multicolumn{8}{|c|}{ Modellere İlişkin İstatistikler } \\
\hline \multicolumn{4}{|c|}{$\mathrm{R}^{2}$} & 0.673 & 0.342 & & \\
\hline \multicolumn{2}{|c|}{$F$-İstatistiği } & & & $8.787^{* * *}$ & $4.892^{* *}$ & & \\
\hline \multicolumn{2}{|c|}{ Olasılık $(F)$} & & & 0.000 & 0.041 & & \\
\hline \multicolumn{2}{|c|}{ DW } & & & 1.937 & 1.884 & & \\
\hline \multicolumn{2}{|c|}{ AIC } & & & 4.975 & 5.696 & & \\
\hline
\end{tabular}

değerlerini ifade etmektedir. 
Tablo 7: Terörizmin Sosyal Belirleyicilerine İlişsin OLS ve GWR Analiz Sonuçları

\begin{tabular}{|c|c|c|c|c|c|c|}
\hline Değişkenler & Minimum & \%25'lik Kartil & GWR & OLS & $\% 75$ 'lik Kartil & Maksimum \\
\hline Sabit (C) & 289.156 & 301.138 & $473.494^{*}(0.091)$ & $286.459(0.245)$ & 562.105 & 565.084 \\
\hline Umut & -0.261 & -0.245 & $-0.193^{* *}(0.028)$ & $-0.122^{*}(0.083)$ & -0.116 & -0.097 \\
\hline Mutluluk & -0.356 & -0.323 & $-0.285^{* *}(0.018)$ & $-0.151^{*}(0.074)$ & -0.149 & -0.121 \\
\hline Suç & 0.0029 & 0.0034 & $0.0035^{* * *}(0.000)$ & $0.0039^{* *}(0.011)$ & 0.0041 & 0.0044 \\
\hline Demokrasi & 13.047 & 13.137 & $14.068^{* * *}(0.003)$ & $13.910^{* *}(0.011)$ & 18.695 & 18.881 \\
\hline Demokrasi $^{2}$ & -0.278 & -0.269 & $-0.217^{* * *}(0.008)$ & $-0.040^{* *}(0.026)$ & -0.037 & -0.013 \\
\hline Etnik & -27.841 & -27.689 & $-26.805^{* * *}(0.002)$ & $-25.637^{* * *}(0.000)$ & -23.220 & -23.062 \\
\hline Kiy1 & 1.144 & 1.160 & $3.601^{*}(0.091)$ & $0.743(0.530)$ & 4.275 & 4.283 \\
\hline Yerleşik & 2.800 & 2.833 & $3.268^{* *}(0.019)$ & $0.239(0.660)$ & 4.848 & 4.861 \\
\hline Çatışma & -2.267 & -2.256 & $-2.177^{* *}(0.044)$ & $-0.024^{*}(0.059)$ & -0.011 & -0.004 \\
\hline Coğrafya & 4.980 & 5.103 & $6.601^{*}(0.096)$ & $1.730(0.371)$ & 12.034 & 12.243 \\
\hline Uzaklık & -0.021 & -0.017 & $-0.015^{* * *}(0.005)$ & $-0.011^{* *}(0.013)$ & -0.009 & -0.003 \\
\hline Kent & -0.126 & -0.113 & $-0.137(0.852)$ & $-0.627(0.971)$ & -0.101 & -0.089 \\
\hline \multicolumn{7}{|c|}{ Modellere İlişkin İstatistikler } \\
\hline $\mathrm{R}^{2}$ & & & 0.671 & 0.354 & & \\
\hline$F$-İstatistiği & & & $5.825^{* * *}$ & $2.391^{*}$ & & \\
\hline Olasilik $(F)$ & & & 0.000 & 0.057 & & \\
\hline DW & & & 1.927 & 1.725 & & \\
\hline AIC & & & 4.257 & 5.626 & & \\
\hline
\end{tabular}

Not: ${ }^{* * *},{ }^{* *}$ ve $^{*}$ işaretleri ilgili katsayısının sırasıyla \%1, \%5 ve \%10 önem düzeyinde anlamlı olduğunu yansıtmaktadır. Parantez içindeki değerler, ilgili katsayıya ait olasılık değerlerini ifade etmektedir. 
Terörizmin makroekonomik belirleyicilerine ilişkin GWR analiz bulgularının sunulduğu Tablo 6, korelasyon sonuçlarını teyit eden nitelikteki sonuçları ortaya koymuştur. Tablo 6'da gösterilen sonuçlar, GWR analizi bağlamında bütün değişkenlerin istatistiki bakımdan anlamlı olduğunu göstermesine karşın; OLS analizi Sabit, Illkokul, Üniversite ve Ticaret değişkenleri dışındaki diğer bağımsız değişkenlerin anlamlı olduğunu ortaya koymuştur. Katsayı işaretleri bakımından beklentilerin karşılandığı GWR analiz bulguları, gelir düzeyinin artmasına paralel olarak terörizmin şiddetlenebileceğini, ancak belirli bir gelir eşik değerine ulaşılmasına bağlı olarak terör eylemlerinin azalma eğilimi içine girebileceğini yansıtmaktadır. Dolayısıyla, gelir düzeyinin terörizmi etkileyen temel mekanizmalardan biri olduğu söylenebilmekle birlikte, eşik sonrası azalan bir trend sergilemesi bağlamında terörizmin arkasında yatan ana unsurun farklı değişkenler itibariyle kendini gösterdiği ifade edilebilmektedir.

Artan nüfus hacmiyle beraber yoksulluk olgusunun kendisini göstereceğini ön plana süren korelasyon bulguları, böylesi bir sonucun terörizmle birleşebileceğini ortaya koymaktadır. İfade edilen sonuç, GWR analizi yardımıyla teyit edilmiş ve artan nüfus hacmine bağlı olarak yoksullukla birleşen düşük gelir düzeyinin terörizmi tetikleyeceğini göstermiştir. Yükselen nüfus potansiyelini terör belâsından kurtarabilmek için eğitimin sürecinin en temel unsur olduğunu gösteren analiz bulguları, her ilave eğitim düzeyine geçişle birlikte terörizmin azalabileceğini yansıtmıştır. Bu bağlamda, terörizme destek verdiği savunulan talep yönlü görüşlerin Türkiye ekonomisi için geçerli olmadığı anlaşılabilmektedir.

İşsizlik, dışa açıklık, enflasyon ve yoksulluk olgularının terörizmi şiddetlendirdiğini yansıtan analiz bulguları, büyüyen gelir pastasının adil dağıtılamaması nedeniyle kendini gösteren gelir eşitsizliğinin de sürece destek verdiğini yansıtmaktadır.

Diğer taraftan, terörizmin sosyal belirleyicilerine ilişkin GWR analiz bulgularının sunulduğu Tablo 7, korelasyon sonuçlarını teyit eden nitelikteki sonuçları ortaya koymuştur. Tablo 7'de gösterilen sonuçlar, GWR analizi bağlamında Kent değişkeni hariç olmak üzere bütün değişkenlerin istatistiki bakımdan anlamlı olduğunu göstermesine karşın; OLS analizi Sabit, Kıyı, Coğrafya, Yerleşik ve Kent değişkenleri dışındaki diğer bağımsız değişkenlerin 
anlamlı olduğunu ortaya koymuştur. Katsayı işaretleri bakımından beklentilerin karşılandığı GWR analiz bulguları, birbirlerinin tamamlayan nitelikte olduğu söylenebilen Umut ve Mutluluk düzeylerinin artmasına paralel olarak gelecek ile ilgili karamsarlığın ortadan kalkabildiği ve buna paralel olarak da terörizmin azalabildiğini yansıtmaktadır. Dolayısıyla, gelecekle ilgili pozitif yönlü bekleyişlerin toplumsal barışa ivme kazandırabileceği vurgulanabilir. Diğer taraftan; Suç değişkeni, şiddet eğiliminin artmasına bağlı olarak terör eylemlerinin ivme kazanabileceği bulgusunu ortaya koymuştur. Ayrıca, hızlanan demokratikleşme sürecinin suç eğilimlerini azaltma yetisine sahip olduğu dikkate alındığında (Demokrasi değişkeni ile Suç değişkeni arasında arasındaki korelasyon katsayısı olan -0.248, \%5 önem düzeyinde istatistiki bakımdan anlamlıdır), demokrasi için belirli bir eşik değerin aşılmasına ve dolayısıyla terörü destekleyen siyasal organın güç kaybetmesine bağlı olarak terörizmin azalacağı vurgulanabilir.

Etnik tabanda kendini gösteren ayrımcılıkların terörizmi şiddetlendirdiğini (negatif katsayı işareti etnik ayrımcılığın arttığının bir göstergesidir) yansıtan analiz bulguları, kıyı kesiminden uzaklaştıkça terör eylemlerinin sıklaştığını ortaya koymaktadır. Terör eylemleri bağlamında Türkiye'nin durumunu doğrulayan bu sonuç, Coğrafya ve Uzaklık değişkenleri itibariyle de teyit edilmiştir. Terör eylemlerinin yoğun olarak gerçekleştiği illere yakın olan lokasyonlarda terörizmin bulaşma etkisinin ortaya çıktığını gösteren analiz bulguları, yoğun terör eylemlerine sahne olan illerden uzaklaştıkça terörün şiddetinin azalabildiğini ortaya koymaktadir.

Bir ilden başka bir ile yönelen göç dalgası paralelinde terör mensuplarının rahatlıkla yer değiştirebildiği argümanından hareket eden yerleşik istikrarsızlığı, bir taraftan terk edilen ilin kendi kaderine terk edilebileceğini, diğer taraftan da nüfusu azalan ilin terör mensupları tarafından kolaylıkla kontrol edilebileceğini yansıtmaktadır. İlgili olguları doğrulayan analiz bulguları, yerleşik istikrarsızlığına bağlı olarak terör eylemlerinin şiddetlenebileceğini göstermiştir. 


\section{Sonuç}

Can ve mal kayıplarının yanı sıra ekonomik ve sosyal deformasyona yol açan terörizm, özellikle 11 Eylül saldırılarını takiben dünya gündeminde adından daha fazla söz ettirmeye başlamıştır. Toplumları sadece ekonomik anlamda değil, sosyal düzeyde de etkileyen terör eylemleri, özellikle yayılma kanalı aracılığıyla etki alanını genişletebilmektedir. Bununla birlikte, terörizmden etkilenen ülkelerin aynı yapısal özelliklere sahip olduğunun varsayıldığı pek çok uygulamalı çalışma, toplumların heterojen özellikler barındırabileceği gerçeğini göz ard1 edebilmektedir. Heterojenite olgusunu dikkate almayan ve global tahmin tekniklerine dayanan böylesi çalışmalar, gerçek durumun gözlenebilmesi noktasında realiteden uzaklaşabilmektedir. Heterejonite ekseninden hareket eden bu çalışmada, terörizmin sosyal ve ekonomik belirleyicileri Türkiye ekonomisinde iller bazında GWR analizi yardımıyla incelenmiştir. Terörizmin belirleyicilerinin saptanmasının yanı sıra, iller arasındaki yakınsama sürecinin incelendiği ve terörizmin bu süreç üzerindeki etkisinin ne olduğu sorusunun cevabının da arandığı bu çalışmada, terörizm ile gelir düzeyi arasında kuadratik (lineer olmayan) bir ilişkinin olup olmadığı da tartışılmıştır.

İfade edilen kapsam dâhilinde ilk olarak Türkiye'deki 80 ilin, 2014 y1lı itibariyle en yüksek kişi başına katma değere sahip il olan İstanbul'a yakınsayıp yakınsamadığı ve terörizmin yakınsama süreci üzerindeki etkisi ikisi koşulsuz ve ikisi ise koşullu olmak üzere dört temel denklem aracılığıyla hesaplanmıştır. Gerek koşulsuz ve gerekse koşullu yakınsama analiz bulguları, iller arasında bir ıraksama sürecinin yaşandığını ve terörizmin ıraksama sürecinin boyutlarını artırdı̆̆ını göstermiştir.

Yakınsama analizini takiben, Türkiye'de terörizmin sosyo-ekonomik belirleyicilerinin incelenebilmesi amacıyla GWR analizinden yararlanılmış ve makroekonomik belirleyiciler ile sosyal belirleyiciler iki ayrı model ekseninde araştırılmıştır. OLS analizine kıyasla GWR analizinin daha tutarlı ve anlamlı sonuçlar verdiğinin gösterildiği analiz bulguları, genel bir ifade ile belirtildiğinde ekonomik yoksunluk ve yoksullaştıran modernizasyon teorilerinin Türkiye için geçerli olduğu sonucunu ortaya koymuştur. 
Bir bütün olarak değerlendirildiğinde, ekonomik büyüme ve demokratikleşme sürecinde belirli bir eşiğe ulaşılmasının terörizme sekte vurabilmek adına önemli bir faktör olduğunu söylemek doğru olsa da, gelir pastasının dilimlenmesi konusunda atılacak adımların ve buradan hareketle de yoksulluk kısır döngüsünü kırmak için uygulanacak politika tedbirlerinin hayati bir önem taşıyacağı söylenebilmektedir. Dolayısıyla, sosyo-kültürel yapının temellerini güçlendirecek makroekonomik politika uygulamaları, Türkiye'de terörizmle mücadele konusunda atılacak adımların öncüsü konumunda olmalıdır. Bu sürecin başlangıç ve dayanak noktaları ise kesintisiz ve sağlam altyapısı olan eğitim kurumlarınca atılabilecektir. Geleceğinden endişe duymayan nesillerin yetiştirilmesinin ancak âdil ve barış ortamının sağlandığı bir sosyo-ekonomik yapıda ortaya çıkacağı göz önünde bulundurulduğunda, milletin bölünmez bütünlüğünü sekteye uğratacak etnik ayrışma sorununa çözüm getirilmesi de hayati bir unsur olarak karşımıza çıkmaktadır. Aksi takdirde, terörizme karşı çözümün sadece haklı gerekçelerle ortaya çıkan askeri müdahaleler kanalıyla kendini göstereceği hususu dikkatlerden kaçırılmaması gereken bir alanı ortaya çıkarabilecek ve böylece kırılmaya elverişli olan toplumsal düzen, terör belâsının öncülük ettiği sosyal karmaşaya doğru bir adım daha atabilecektir.

\section{KAYNAKÇA}

Akhmat, G., Zaman, K., Shukui, T. ve Sajjad, F. (2014). Exploring the Root Causes of Terrorism in South Asia: Everybody Should Be Concerned. Quality \& Quantity. 48(6), 3065-3079.

Akıncı, M. ve Yılmaz, Ö. (2015). Bir Turizm Krizi Olarak Uluslararası Terörizm: Ülke Grupları İtibariyle Panel Veri Analizi. Kocaeli Üniversitesi Sosyal Bilimler Dergisi. 30(2), 5176.

Akıncı, M., Yüce-Akıncı, G. ve Yılmaz, Ö. (2015). Terörizmin Doğrudan ve Dolaylı Yatırımlar Üzerindeki Etkisi: Dış Yardımlar Ne Kadar Telafi Edici?. Ankara Üniversitesi SBF Dergisi. 70(1), 1-33.

Akyüz, K. ve Armstrong, T. (2011). Understanding the Sociostructural Correlates of Terrorism in Turkey. International Criminal Justice Review. 21(2), 134-155. 
Barro, R. J. ve Sala-i-Martin, X. (1991). Convergence Across States and Regions. Brookings Papers on Economic Activity. 1, 107-182.

Benmelech, E., Berrebi, C. ve Klor, E. F. (2012). Economic Conditions and the Quality of Suicide Terrorism. The Journal of Politics. 74(1), 113-128.

Bergesen, A. J. ve Lizardo, O. (2004). International Terrorism and the World-System. Sociological Theory. 22(1), 38-52.

Berrebi, C. ve Ostwald, J. (2013). Earthquakes, Hurricanes and Terrorism: Do Natural Disasters Incite Terror?. Public Choice. 149(3-4), 383-403.

Blau, P. M. (1977). Inequality and Heterogeneity. New York: Free Press.

Blau, P. M., Blum, T. C. ve Schwartz, J. E. (1982). Heterogeneity and Intermarriage. American Sociological Review. 47(1), 45-62.

Blomberg, S. B. ve Hess, G. D. (2006). From (No) Butter to Guns? Understanding the Economic Role in Transnational Terrorism. SSRN Working Paper, No: 904026.

Blomberg, S. B. ve Rosendorff, B. P. (2006). A Gravity Model of Globalization, Democracy and Transnational Terrorism. USC Working Paper, No: C06-6.

Bravo, A. B. S. ve Dias, C. M. M. (2006). An Empirical Analysis of Terrorism: Deprivation, Islamism and Geopolitical Factors. Defence and Peace Economics. 17(4), 329-341.

Brockhoff, S., Krieger, T. ve Meierrieks, D. (2014). Great Expectations and Hard Times: The (Nontrivial) Impact of Education on Domestic Terrorism. Journal of Conflict Resolution. 19, 1-30.

Burgoon, B. (2006). On Welfare and Terror: Social Welfare Policies and Political-Economic Roots of Terrorism. Journal of Conflict Resolution. 50(2), 176-203.

Campos, N. F. ve Gassebner, M. (2009). International Terrorism, Political Instability and the Escalation Effect. IZA Working Paper, No: 4061. 
Caruso, R. ve Schneider, F. (2013). Brutality of Jihadist Terrorism: A Contest Theory Perspective and Empirical Evidence in the Period 2002-2010. Journal of Policy Modeling. 35(5), 685-696.

Choi, S. W. (2015). Economic Growth and Terrorism: Domestic, International and Suicide. Oxford Economic Papers. 67(1), 157-181.

Coggins, B. L. (2015). Does State Failure Cause Terrorism? An Empirical Analysis (19992008). Journal of Conflict Resolution. 59(3), 455-483.

Cruz-Lugovskyy, J. (2014). The Economic Determinants of Terrorism. International Journal of the Academic Business World. 8(2), 51-61.

Daniel, G., Arce, M. ve Sandler, T. (2003). An Evolutionary Game Approach to Fundamentalism and Conflict. Journal of Institutional and Theoretical Economics. 159(1), 132-154.

Derin-Güre, P. ve Elveren, A. Y. (2014). Does Income Inequality Derive the Separatist Terrorism in Turkey?. Defence and Peace Economics. 25(3), 311-327.

DiPietro, W. R. (2015). Terrorism and National Morality. Journal of Economics and Public Finance. 1(1), 1-9.

Dreher, A. ve Fischer, J. A. V. (2010). Government Decentralization as a Distinctive for Transnational Terror? An Empirical Analysis. International Economic Review. 51(4), 981-1002.

Fotheringham, A. S., Charlton, M. E. ve Brunsdon, C. (1997). Measuring Spatial Variations in Relationships with Geographically Weighted Regression. Fisher, M. M. ve Getis, A. (Eds.). Recent Developments in Spatial Analysis içinde (ss. 60-85). Berlin: Springer.

Freytag, A., Krüger, J. J., Meierrieks, D. ve Schneider, F. (2011). The Origins of Terrorism: Cross-Country Estimates of Socio-Economic Determinants of Terrorism. European Journal of Political Economy. 27(1), 5-16. 
Goldstein, K. B. (2005). Unemployment, Inequality and Terrorism: Another Look at the Relationship Between Economics and Terrorism. Undergraduate Economic Review. $1(1), 1-21$.

Gries, T. ve Meierrieks, D. (2013). Do Banking Crisis Cause Terrorism?. Economics Letters. 199(3), 321-324.

Gurr, T. (1968). Psychological Factors in Civil Violence. World Politics. 20(2), 245-278.

Hamilton, L. C. ve Hamilton, J. D. (1983). Dynamics of Terrorism. International Studies Quarterly. 27(1), 39-54.

Huntington, S. (1996). The Clash of Civilizations and the Remarking of World Order. New York: Simon \& Schuster.

Ismail, A. ve Amjad, S. (2014). Determinants of Terrorism in Pakistan: An Empirical Investigation. Economic Modelling. 37, 320-331.

Kis-Katos, K., Liebert, H. ve Schulze, G. G. (2011). On the Origin of Domestic and International Terrorism. European Journal of Political Economy. 27(1), 17-36.

Krieger, T. ve Meierrieks, D. (2010). Terrorism in the Worlds of Welfare Capitalism. Journal of Conflict Resolution. 54(6), 902-939.

Krieger, T. ve Meierrieks, D. (2011). What Causes Terrorism. Public Choice. 147(1), 3-27.

Krueger, A. B. ve Maleckova, J. (2003). Education, Poverty and Terrorism: Is There a Causal Connection?. The Journal of Economic Perspectives. 17(4), 119-144.

Midlarsky, M. I., Crenshaw, M. ve Yoshida, F. (1980). Why Violence Spreads: The Contagion of International Terrorism. International Studies Quarterly. 24(2), 262-298.

Mirza, D. ve Verdier, T. (2008). International Trade, Security and Transnational Terrorism: Theory and a Survey of Empirics. Journal of Comparative Economics. 36(2), 179-194. 
Murdie, A. ve Stapley, C. S. (2014). Why Target the 'Good Guys'? The Determinants of Terrorism Against NGOs. Empirical and Theoretical Research in International Relations. 40(1), 79-102.

Olson, M. (1963). Rapid Growth as a Destabilizing Force. The Journal of Economic History. 23(4), 529-552.

Öcal, N. ve Y1ldırım, J. (2010). Regional Effects of Terrorism on Economic Growth in Turkey: A Geographically Weighted Regression Approach. Journal of Peace Research. 47(4), 477-489.

Robison, K. K., Crenshaw, E. M. ve Jenkins, J. C. (2006). Ideologies of Violence: The Social Origins of Islamist and Leftist Transnational Terrorism. Social Forces. 84(4), 20092026.

Romer, P. M. (1986). Increasing Returns and Long-Run Growth. Journal of Political Economy. 94(5), 1002-1037.

Savun, B. ve Phillips, B. J. (2009). Democracy, Foreign Policy and Terrorism. Journal of Conflict Resolution. 53(6), 878-904.

Shahbaz, M. (2013). Linkages Between Inflation, Economic Growth and Terrorism in Pakistan. Economic Modelling. 32, 496-506.

Shahbaz, M. ve Shabbir, S. M. (2011). Is Hike in Inflation Responsible for Rise in Terrorism in Pakistan?. MPRA Working Paper, No: 31236.

Solow, R. M. (1956). A Contribution to the Theory of Economic Growth. The Quarterly Journal of Economics. 70(1), 65-94.

Sönmez, S. ve Graefe, A. R. (1998). Influence of Terrorism Risk on Foreign Tourism Decisions. Annals of Tourism Research. 25(1), 112-144. 
Tavares, J. (2004). The Open Society Assesses Its Enemies: Shocks, Disasters and Terrorist Attacks. Journal of Monetary Economics. 51(5), 1039-1070.

Testas, A. (2004). Determinants of Terrorism in the Muslim World: An Empirical Cross-Sectional Analysis. Terrorism and Political Violence. 16(2), 253-273.

Yıldırım, J., Öcal, N. ve Korucu, N. (2007). Analysing the Determinants of Terrorism in Turkey using Geographically Weighted Regression. Erişim Tarihi: 04.01.2016 http://www.ub.edu/sea2009.com/Papers/10.pdf

Yıldırım, J. ve Öcal, N. (2013). Analysing the Determinants of Terrorism in Turkey using Geographically Weighted Regression. Defence and Peace Economics. 24(3), 195-209. 